\title{
Population Viability Analysis of the Endangered Shortnose Sturgeon
}

December, 2011 


\section{DOCUMENT AVAILABILITY}

Reports produced after January 1, 1996, are generally available free via the U.S. Department of Energy (DOE) Information Bridge.

Web site http://www.osti.gov/bridge

Reports produced before January 1, 1996, may be purchased by members of the public from the following source.

National Technical Information Service

5285 Port Royal Road

Springfield, VA 22161

Telephone 703-605-6000 (1-800-553-6847)

TDD 703-487-4639

Fax 703-605-6900

E-mailinfo@ntis.fedworld.gov

Web site http://www.ntis.gov/support/ordernowabout.htm

Reports are available to DOE employees, DOE contractors, Energy Technology Data Exchange (ETDE) representatives, and International Nuclear Information System (INIS) representatives from the following source.

Office of Scientific and Technical Information

P.O. Box 62

Oak Ridge, TN 37831

Telephone 865-576-8401

Fax 865-576-5728

E-mail reports@adonis.osti.gov

Web site http://www.osti.gov/contact.html

This report was prepared as an account of work sponsored by an agency of the United States Government. Neither the United States Government nor any agency thereof, nor any of their employees, makes any warranty, express or implied, or assumes any legal liability or responsibility for the accuracy, completeness, or usefulness of any information, apparatus, product, or process disclosed, or represents that its use would not infringe privately owned rights. Reference herein to any specific commercial product, process, or service by trade name, trademark, manufacturer, or otherwise, does not necessarily constitute or imply its endorsement, recommendation, or favoring by the United States Government or any agency thereof. The views and opinions of authors expressed herein do not necessarily state or reflect those of the United States Government or any agency thereof. 


\section{Population Viability Analysis of the Endangered Shortnose Sturgeon}

RC-1543

2011 Final Report

Date published: December 2011

Henriette I. Jager and Mark S. Bevelhimer

Environmental Sciences Division

Oak Ridge National Laboratory

Doug L. Peterson

Warnell School of Forestry and Natural Resources

University of Georgia

Prepared by

OAK RIDGE NATIONAL LABORATORY

Oak Ridge, Tennessee 37831

managed by

UT-BATTELLE, LLC

for the

U.S. DEPARTMENT OF ENERGY

Under contract DE-AC05-00OR22725 


\begin{tabular}{|c|c|c|c|c|c|c|}
\hline \multicolumn{6}{|c|}{ REPORT DOCUMENTATION PAGE } & $\begin{array}{l}\text { Form Approved } \\
\text { DMB No. 0704-0188 }\end{array}$ \\
\hline \multicolumn{7}{|c|}{ 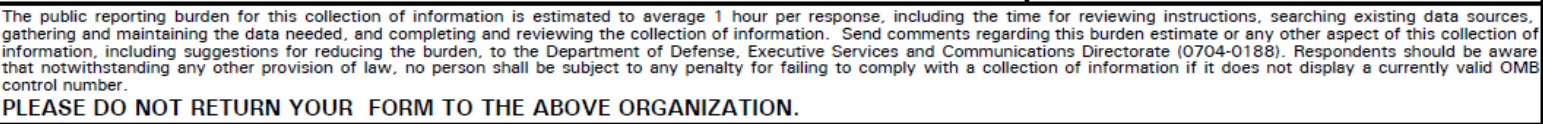 } \\
\hline \multicolumn{2}{|c|}{$\begin{array}{l}\text { 1. REPORT DATE (DD-MM-YYYY) } \\
15-07-2011\end{array}$} & \multicolumn{3}{|c|}{\begin{tabular}{|ll} 
2. REPORT TYPE & Final \\
\end{tabular}} & 3. DATES & OVERED (From - To) \\
\hline \multicolumn{5}{|c|}{$\begin{array}{l}\text { 4. TITLE AND SUBTITLE } \\
\text { Population Viability Analysis of the Endangered Shortnose Sturgeon }\end{array}$} & \multicolumn{2}{|c|}{ 5a. CONTRACT NUMBER } \\
\hline & & & & & \multicolumn{2}{|l|}{ 5b. GRANT NUMBER } \\
\hline & & & & & \multicolumn{2}{|c|}{ 5c. PROGRAM ELEMENT NUMBER } \\
\hline \multirow{3}{*}{\multicolumn{5}{|c|}{$\begin{array}{l}\text { 6. AUTHOR(S) } \\
\text { Henriette I. Jager and Mark S. Bevelhimer - Oak Ridge National Laboratory } \\
\text { Doug Peterson - University of Georgia at Athens }\end{array}$}} & \multicolumn{2}{|c|}{$\begin{array}{l}\text { 5d. PROJECT NUMBER } \\
\qquad \mathrm{RC}-1543\end{array}$} \\
\hline & & & & & \multicolumn{2}{|l|}{ 5e. TASK NUMBER } \\
\hline & & & & & \multicolumn{2}{|c|}{ 5f. WORK UNIT NUMBER } \\
\hline \multicolumn{5}{|c|}{$\begin{array}{l}\text { 7. PERFORIING ORGANIZATION NAME(S) AND ADDRESS(ES) } \\
\text { Environmental Sciences Division, Oak Ridge National Laboratory } \\
\text { PO Box } 2008 \\
\text { Oak Ridge, TN } 37831-6036\end{array}$} & $\begin{array}{l}\text { 8. PERFOR } \\
\text { REPORT }\end{array}$ & $\begin{array}{l}\text { NG ORGANIZATION } \\
\text { UMBER } \\
\text { DRNL/TM-2011/48 }\end{array}$ \\
\hline \multirow{2}{*}{\multicolumn{5}{|c|}{$\begin{array}{l}\text { 9. SPONSORING/MONITORING AGENCY NAME(S) AND ADDRESS(ES) } \\
\text { Strategic Environmental Research and Development Program }\end{array}$}} & 10. SPONS & R/MONITOR'S ACRONYM(S) \\
\hline & & & & & $\begin{array}{l}\text { 11. SPONS } \\
\text { NUMB }\end{array}$ & $\begin{array}{l}\text { R/MONITOR'S REPORT } \\
\text { (S) }\end{array}$ \\
\hline \multicolumn{7}{|c|}{ 12. DISTRIBUTION/AVAILABILITY STATEMENT } \\
\hline \multicolumn{7}{|c|}{ 13. SUPPLEMENTARY NOTES } \\
\hline \multicolumn{7}{|c|}{ 14. ABSTRACT } \\
\hline \multirow{2}{*}{\multicolumn{7}{|c|}{$\begin{array}{l}\text { Objective: Three goals of this research were: (1) to quantitatively partition the influences on shortnose sturgeon (Acipenser } \\
\text { brevirostrum) recovery under the control of the military from those that are not, (2) to prioritize recovery efforts, and ( } 3 \text { ) to quantify } \\
\text { population thresholds. A workshop brought together experts to help identify potential threats including groundwater withdrawal, } \\
\text { poor water quality in summer, saltwater intrusion via rice canals, mercury effects, harvest as by-catch, and sedimentation of } \\
\text { spawning habitat. Population viability analysis (PVA) was proposed as a method to partition the influences of potential threats to } \\
\text { this endangered fish. } \\
\text { Methodology: We assessed and ranked potential threats to population recovery. A workshop ruled out two potential threats. Models } \\
\text { were developed to assess two potential threats to sturgeon growth and reproduction: high summer water temperatures and mercury u }\end{array}$}} \\
\hline & & & & & & \\
\hline \multicolumn{7}{|c|}{$\begin{array}{l}\text { 15. SUBJECT TERMS } \\
\text { population viability analysis, shortnose sturgeon, Ogeechee River, Fort Stewart, blackwater river, mercury bioaccumulation, } \\
\text { by-catch harvest, minimum river habitat length, rice canals, headwater watersheds, military training, sedimentation, dissolved oxyge }\end{array}$} \\
\hline \multicolumn{3}{|c|}{ 16. SECURITY CLASSIFICATION OF: } & 17. LIMITATION OF & 18. NUMBER & \multicolumn{2}{|c|}{ 19a. NAME OF RESPONSIBLE PERSON } \\
\hline a. REPORT & \multicolumn{2}{|c|}{\begin{tabular}{l|l|} 
b. ABSTRACT & c. THIS PAGE
\end{tabular}} & ABSTRACT & $\begin{array}{l}\text { OF } \\
\text { PAGES }\end{array}$ & \multicolumn{2}{|c|}{ 19b. TELEPHONE NUMBER (Include area code) } \\
\hline & & & & & Reset & $\begin{array}{l}\text { Standard Form } 298 \text { (Rev. 8/98) } \\
\text { Prescribed by ANSI Std. Z39.18 }\end{array}$ \\
\hline
\end{tabular}




\section{TABLE OF CONTENTS}

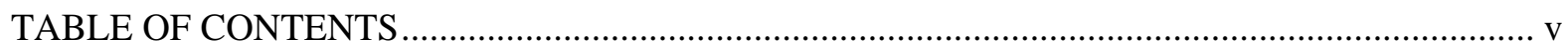

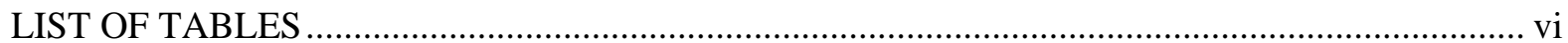

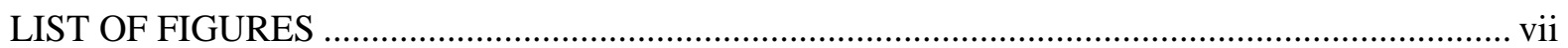

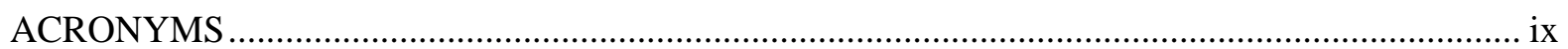

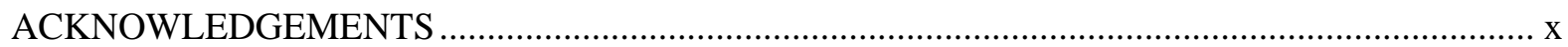

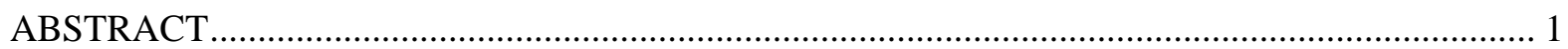

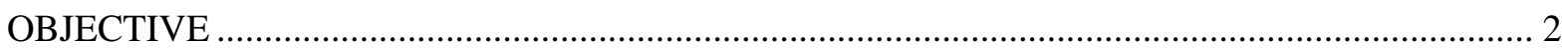

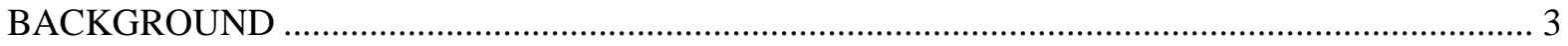

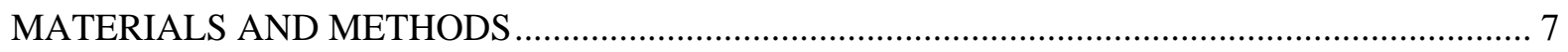

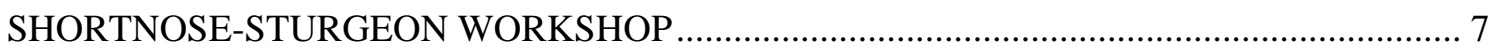

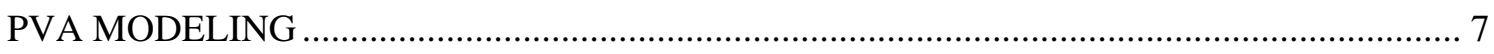

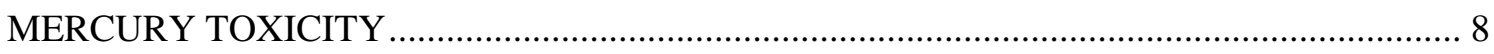

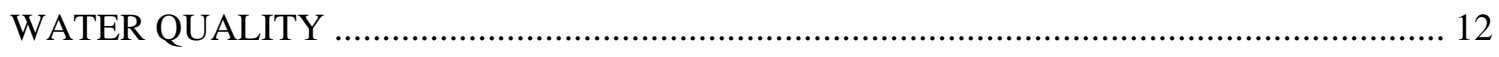

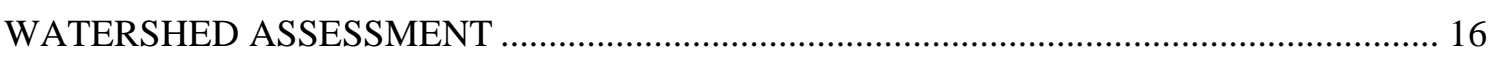

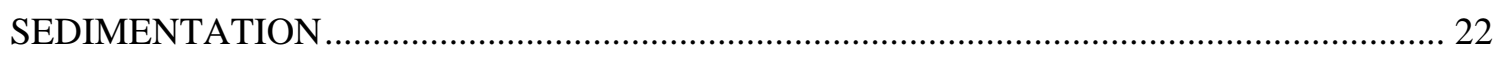

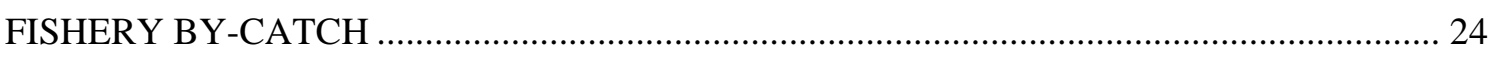

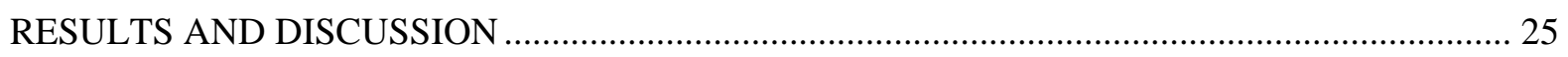

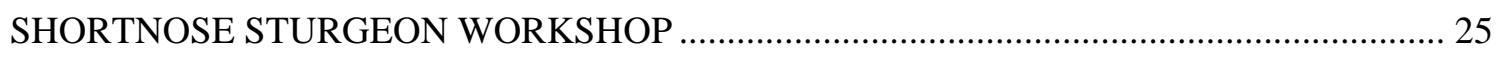

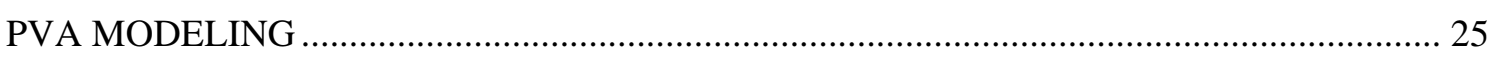

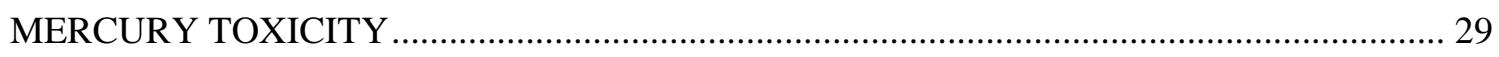

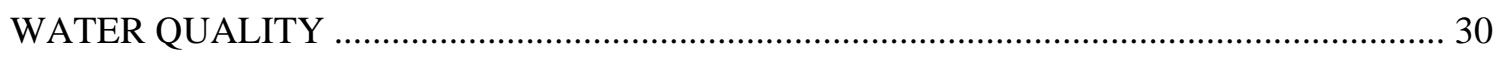

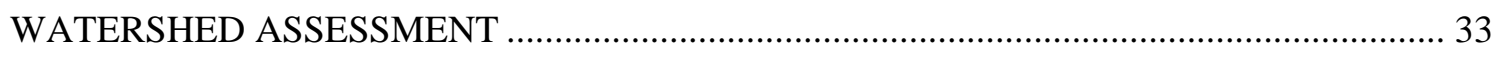

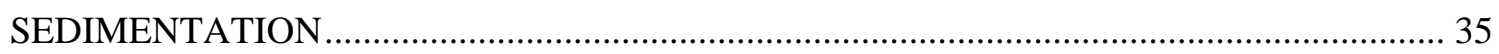

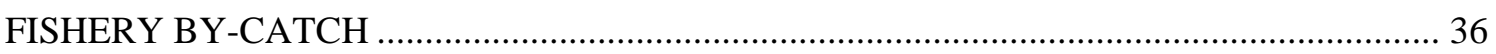

CONCLUSIONS AND IMPLICATIONS FOR FUTURE RESEARCH........................................ 37

POPULATION RECOVERY: PVA-BASED EVIDENCE FOR HABITAT AND SPAWNER

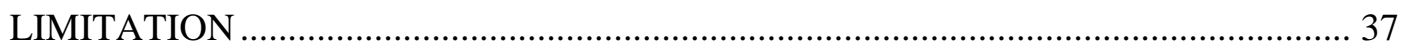

SUMMER WATER QUALITY LIMITS PVA-SIMULATED POPULATION RECOVERY .. 38 COARSE SUBSTRATE REQUIRED FOR SPAWNING IS RARE........................................ 38

SIMULATED MERCURY CONCENTRATIONS ARE BELOW EPA'S THRESHOLD........ 39

HARVEST MORTALITY LIMITS PVA-SIMULATED POPULATION RECOVERY .......... 40

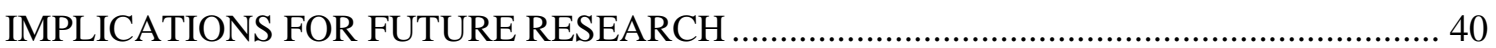

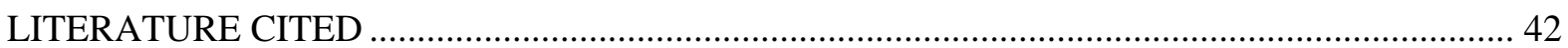

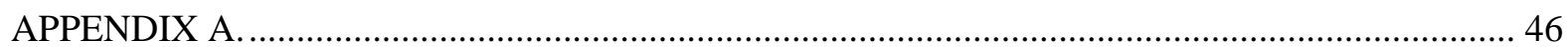

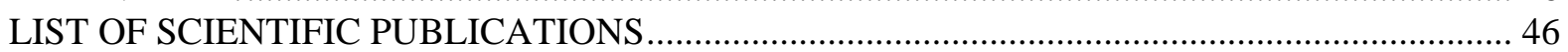




\section{LIST OF TABLES}

Table 1. List frame of accessible headwater watersheds on Fort Stewart and subsets representing those sampled. Lab ids in column 1 with 'A' appended indicate sites replaced after 2008, and replacement sites are indicated by a ' $\mathrm{B}$ '. History codes indicate headwater accessible watersheds in list frame: $0=$ not in candidate sample, not sampled; $1=$ not in candidate sample, sampled; $2=$ candidate sample, not sampled (excluded during site visit); $3=$ candidate sample, sampled.

Table 2. Classification scheme developed by Litts, Kaiser, and Wes Tracy to identify habitat from sidescan sonar data.

Table 3. Location, size, depth, and composition of potentially suitable spawning grounds for Atlantic sturgeon $(>1.5 \mathrm{~m})$ and shortnose sturgeon $(>2.2 \mathrm{~m})$ in the Ogeechee River, Georgia. Source: Hook (2011) 


\section{LIST OF FIGURES}

Figure 1. Historical estimates of population sizes for the Ogeechee River shortnose sturgeon population. Source: Farrae 2010.

Figure 2. Map of the Lower Ogeechee River, Georgia. Source: Farrae 2010.

Figure 3. Hypothesized effects (blue) of potential threats (green) that might influence shortnose sturgeon recovery in the Ogeechee River.

Figure 4. Simulated average daily growth in weight over twenty years showing positive growth in the winter and negative growth in summer (solid line). On the $\mathrm{x}$-axis, years are labeled in winter ( Jan 1$)$ and mid-summer is indicated by upward ticks. The ratio of simulated fish lengths to those expected based on field measurements fluctuated around the desired value of one (dash-dotted line).

Figure 5. Diagramatic representation of energy allocation in the white sturgeon bioenergetic model of Bevelhimer (2002).

Figure 6. Stella ${ }^{\mathrm{TM}}$ model to simulate contaminant uptake. Dashed shapes are simulated stocks (boxes) and converters (circles) from the bioenergetics model.

Figure 7. Schematic map of bridge sample locations overlaid on a Google satellite map that indicates barren training areas (dotted outline) on Fort Stewart. Note also the contrast between developed areas surrounding Fort Stewart and the amount of forested and other less-developed land within the installation.

Figure 8. Accessible, headwater watersheds included in our sample in the western portion of Fort Stewart, Georgia. Watershed id's refer to those in Table 1.

Figure 9. Ten-year time series for each of 30 replicate shortnose sturgeon populations starting with an initial population of 150 individuals and 1985-1995 historical climate and river flow. Results are shown for three river lengths, 83, 100, and $125 \mathrm{~km}$, corresponding to the simulated location of spawning.

Figure 10. Model-predicted increase in population persistence over 50 y for different initial population sizes. We simulated immigration for the open population but not for the isolated population.

Figure 11. Model-simulated shortnose sturgeon population dynamics and prey dynamics over a twentyyear simulation.

Figure 12. Fraction of 100 replicate populations (white) that persisted and the average number of adults produced (black) and over a twenty-year period for each of five scenarios in which factors were removed. Values presented are for an initial population size of 225 individuals. Error bars indicate \pm 1 SE among replicate scenarios.

Figure 13. Average simulated mortality with all sources of mortality, without harvest, without rice canals, and without any sources of habitat mortality, and without any of the three factors. Values are averaged over 100 replicate simulations for an initial population size of 225 individuals.

Figure 14. Simulated whole body total $\mathrm{Hg}$ in shortnose sturgeon for two prey concentrations that bracket values measured in Ogeechee River amphipods.

Figure 15. Comparison of measured data and model-predicted whole-body concentrations in amphipod prey (solid bars), shortnose sturgeon (striped bars), and shortnose sturgeon eggs (open bars) for two levels bracketing measured prey concentrations.

Figure 16. Distributions of bi-weekly dissolved oxygen measurements in summer months (June to Sept) and winter months (Nov - Mar), 2007 to 2009 in the lower Ogeechee River. Each box extends from the lower $25^{\text {th }}$ to the $75^{\text {th }}$ percentile, with the median and mean shown as solid and dashed horizontal lines, respectively. Upper and lower whiskers indicate $5^{\text {th }}$ and $95^{\text {th }}$ percentiles, and symbols show extreme 
values.

Figure 17. Water chemistry measurements, including A) nitrogen, B) phosphorus, C) total suspended solids (TSS), and dissolved organic carbon (DOC), taken from six bridges on the lower Canoochee River on two occasions (August 2008 and August 2009). Bridges 15 and 19 are on the upper branch of the Canoochee River. Bridges 27 and 28 are located below Taylor Creek on Canoochee Creek. Bridges 38 and 40 are located on the Canoochee River downstream of the Canoochee Creek confluence and downstream of a large, barren area used for training.

Figure 18. Water chemistry measurements from headwater watersheds on Fort Stewart, Georgia. Each box extends from the lower $25^{\text {th }}$ to the $75^{\text {th }}$ percentile, with the median and mean shown as solid and dashed horizontal lines, respectively. Upper and lower whiskers indicate $5^{\text {th }}$ and $95^{\text {th }}$ percentiles, and symbols show extreme values. Two groups are shown: A) Concentrations of total suspended sediment (TSS), dissolved (DOC), and total organic carbon (TOC) are reported in $\mathrm{mg} \mathrm{L}^{-1}$; B) Concentrations of $\mathrm{NH}_{4}{ }^{+}$, nitrate plus nitrite $\left(\mathrm{NO}_{3}\right)$, and total organic nitrogen (TON) are in $\mathrm{mg} \mathrm{N} \mathrm{L}^{-1}$. Concentrations of soluble reactive phosphorus, $\mathrm{SRP}$, and total phosphorus (TP) are in $\mathrm{mg} \mathrm{P} \mathrm{L}^{-1}$.

Figure 19. Potentially suitable spawning locations for Atlantic and shortnose sturgeon in the Ogeechee River, Georgia (river km). Results indicate low substrate diversity dominated by silt/sand substrate. 


\section{ACRONYMS}

$\begin{array}{ll}\text { DO } & \text { Dissolved oxygen } \\ \text { DOC } & \text { Dissolved organic carbon } \\ \text { EFDC } & \text { Environmental Fluid Dynamics Code } \\ \text { NH4 } & \text { Ammonium } \\ \text { NO3 } & \text { Nitrate plus nitrite } \\ \text { MeHg } & \text { Methyl mercury } \\ \text { MVP } & \text { Minimum viable population size } \\ \text { OC } & \text { Organic carbon } \\ \text { ON } & \text { Organic nitrogen } \\ \text { ORNL } & \text { Oak Ridge National Laboratory } \\ \text { PO4 } & \text { Phosphate } \\ \text { PVA } & \text { Population viability analysis } \\ \text { RFMSS } & \text { Range Facility Management Support System } \\ \text { SERDP } & \text { Strategic Environmental Research and Development } \\ \text { SRP } & \text { Soluble reactive phosphorus } \\ \text { TN } & \text { Total nitrogen } \\ \text { TOC } & \text { Total organic carbon } \\ \text { TP } & \text { Total phosphate } \\ \text { TSS } & \text { Total suspended solids } \\ \text { UGA } & \text { University of Georgia } \\ \text { USGS } & \text { U.S. Geological Survey } \\ & \end{array}$




\section{ACKNOWLEDGEMENTS}

First and foremost, we appreciate the contributions of Daniel Farrae (University of Georgia, Athens) and Roy King (Fort Stewart), who's field efforts provided water samples needed to conduct much of the field component of this research. We thank Fort Stewart personnel, including Tim Beaty, Robert Gosnell, and Larry Carlile for their support, providing GIS data, GPS equipment, and feedback on evaluating training activities. Katy Smith (UGA MAREX lab in Brunswick, GA) conducted most of the chemical analyses of samples from headwater streams through a subcontract managed by Keith Gates. Thanks to other researchers involved in the project at the University of Georgia, Athens. We appreciate the contribution of Dr. Nate Nibbelink and John Hook who conducted a survey of the Ogeechee River using side-scan sonar imagery that contributed to our understanding of sturgeon spawning habitat. We appreciate advice from Dr. Patrick Mulholland (ORNL) regarding water quality and the watershed study, and his willingness to review our results. This research was performed at Oak Ridge National Laboratory (ORNL) and sponsored by the US Department of Defense Strategic Environmental Research and Development Program (SERDP) through military interagency purchase requisition no. W74RDV83465697. We appreciate the assistance provided by John Hall (program manager), SERDP Office staff and HGL support staff. ORNL is managed by UT-Battelle, LLC, for the US Department of Energy under contract DE-AC05-00OR22725. 


\begin{abstract}
Objective: Population viability analysis (PVA) can be used to partition influences on population recovery, and to distinguish those under the control of the military. We used PVA to evaluate threats to recovery of shortnose sturgeon (Acipenser brevirostrum) in a river adjacent to Fort Stewart, Georgia, USA. We evaluated potential threats including groundwater withdrawal, poor water quality in summer, saltwater intrusion via rice canals, mercury effects, harvest as by-catch, and sedimentation of spawning habitat.
\end{abstract}

Methodology: We assessed and ranked potential threats to population recovery using PVA. A workshop ruled out groundwater withdrawal and sedimentation of spawning habitat caused by activities on Fort Stewart. Models were developed to assess two potential threats to sturgeon growth and reproduction: high summer water temperatures and mercury uptake. To assess effects of summer water quality, we monitored temperature, salinity, and dissolved oxygen in the Canoochee and Ogeechee Rivers and used these to model and simulate spatial and temporal variation in water quality. In addition, we conducted a side-scan sonar survey of sediments to evaluate the availability of sturgeon spawning habitat. We developed a sophisticated riverine PVA model to simulate sturgeon growth, survival, and reproduction in response to water quality, saltwater intrusion via rice canals, and harvest. Simulation experiments that removed potential threats evaluated their effects on short-term extinction risk. To examine Fort Stewart's influence on water quality, a novel survey of headwater watersheds was designed with the goal of minimizing correlation among predictors and including watersheds with extreme land-use characteristics. We then developed relationships between water quality and watershed attributes, including military training activities.

Results and Discussion: During the course of the project, we eliminated two threats and focused on the remaining four. We identified six putative spawning locations with coarse substrate in deep pools. PVA simulations found poor water quality, saltwater intrusion, and by-catch mortality to have significant individual and interactive influences on persistence. Of these, only water quality is potentially influenced by Fort Stewart's activities and we found that military training was associated with higher suspended sediment and organic carbon in Fort Stewart's headwater streams. Downstream, dissolved oxygen in the Ogeechee River was frequently below levels considered suitable for sturgeons. Future research is needed to understand populations in southern rivers as a metapopulation and the effects of climate variation on summer habitat and winter connectivity.

KEYWORDS; population viability analysis, shortnose sturgeon, Ogeechee River, Fort Stewart, blackwater river, mercury bioaccumulation, by-catch harvest, minimum river habitat length, rice canals, headwater watersheds, military training, sedimentation, spawning habitat, dissolved oxygen, Atlantic sturgeon 


\section{OBJECTIVE}

Population viability analysis (PVA) provides a scientific basis for assessing cumulative and separate effects through a combination of empirical analysis and modeling. Mechanistic PVA models make it possible to partition the influences of contributing factors, with the goal of prioritizing recovery efforts. Three goals of this research were: (1) to quantitatively partition the influences on shortnose sturgeon recovery under the control of the military from those that are not, (2) to prioritize recovery efforts, and (3) to quantify population thresholds. Our modeling research quantified the cumulative and separate effects of the factors listed above on the long-term persistence of the shortnose sturgeon population in the Ogeechee River, adjacent to Fort Stewart. Our empirical research improved our understanding of challenges shared by other fishes and rivers, including mercury effects and the effects of watershed management, rice canals, and climate change on water quality and shortnose sturgeon habitat.

We conducted a coordinated field and modeling effort to quantify cumulative effects on the endangered shortnose sturgeon near Fort Stewart. We designed and implemented a mechanistic, spatial PVA model that links sturgeon population dynamics to water quality (salinity, temperature, dissolved oxygen). These linkages depended on modeling the physical habitat and developing empirical relationships between individual sturgeon growth, survival and reproduction and the river habitat, which is influenced by activities in the surrounding watersheds. These relationships were obtained both by analyzing existing data and by collecting data to fill critical information gaps. We estimated the importance of each factor by comparing the likelihood of persistence predicted with all factors simulated to those predicted removing one risk factor at a time--a virtual experiment that would not otherwise be possible.

Our primary objective was to combine empirical and model-based research to determine which of various factors, if mitigated, would be most likely to lead to recovery of the shortnose sturgeon population in the Ogeechee River, and which of those are influenced by activities on Fort Stewart. The PVA modeling approach evaluated the importance of each factor influencing shortnose sturgeon and addressed the following scientific questions:

1. Is the population limited by habitat or spawner numbers, in the absence of other influences?

a. What is the minimum viable population size?

b. What is the minimum amount of habitat required for persistence?

c. Do rice canals have a significant negative effect on juvenile habitat?

2. Is summer water quality limiting the Ogeechee River population?

3. Is availability of coarse substrate limiting spawning in the Ogeechee River?

4. Is mercury limiting the Ogeechee River population?

5. Is harvest mortality as by-catch limiting the Ogeechee River population? 


\section{BACKGROUND}

Rivers and estuaries along the Atlantic coast support both military installations and populations of the federally endangered shortnose sturgeon (Acipenser brevirostrum). This project focuses on the population in the Ogeechee River system, near Fort Stewart, an unimpounded blackwater river. The Ogeechee River, as an individual population segment, contains an order of magnitude fewer sturgeon than the neighboring Altamaha River (DeVries 2006) and two orders of magnitude fewer fish than the largest known population in the Hudson River (Bain et al. 2007). Population estimates for this population have varied between 75 and 400 individuals since 1990 (Figure 1; Peterson and Farrae 2011). Fort Stewart is the largest military installation in the southeastern US, nearly all of which drains to the Canoochee River (Figure 2), a tributary of the Ogeechee River.

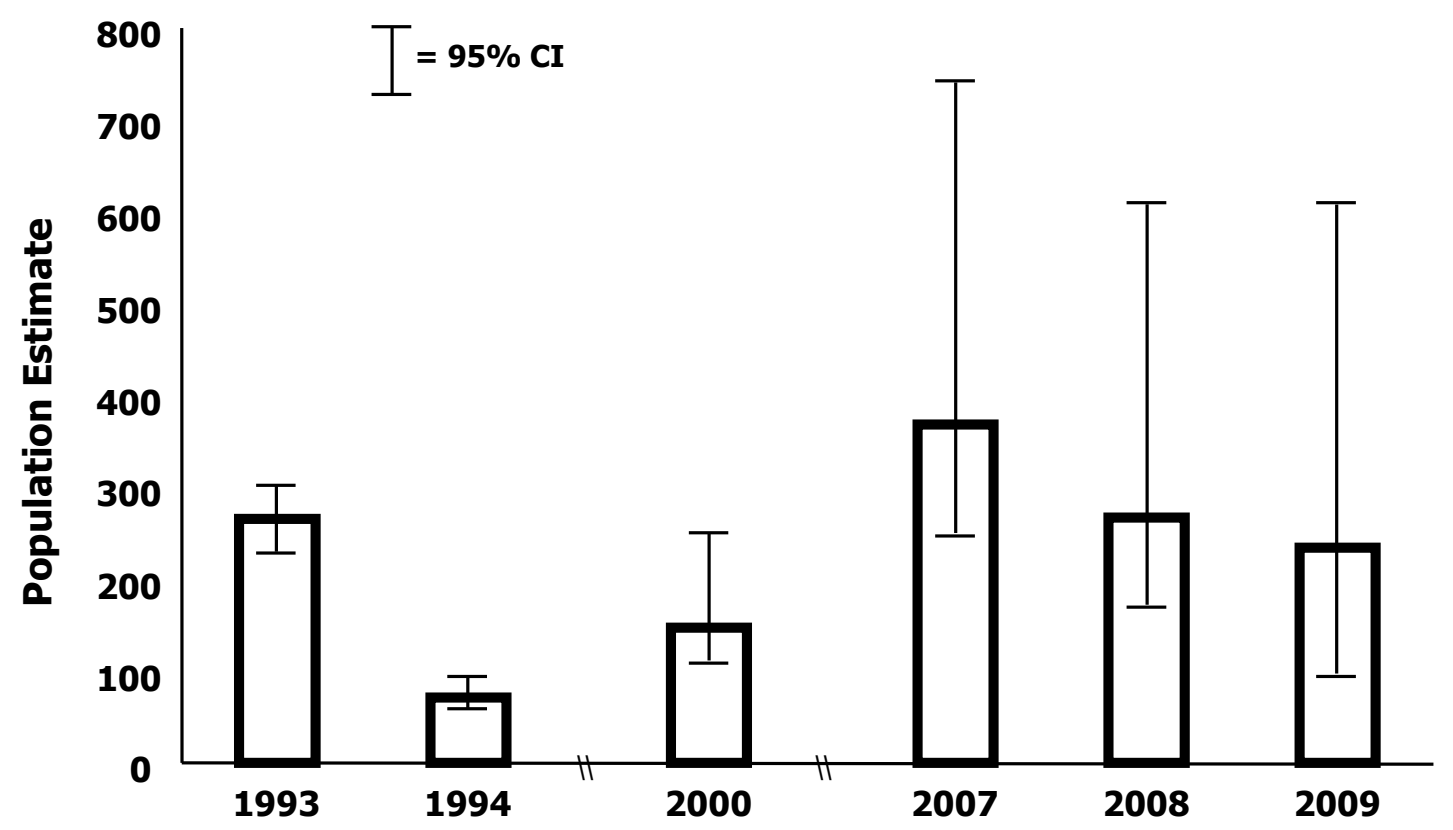

Weber et al. $\quad$ Fleming et al.

Farrae

Figure 1. Historical estimates of population sizes for the Ogeechee River shortnose sturgeon population. Source: Farrae 2010.

Farrae and Peterson (2010) estimated current abundance, annual survival, and temporary emigration parameters of Ogeechee River shortnose sturgeon population from 2007 - 2009, as shown in Figure 2. Their research, which was carried out as a complementary project to this one, fulfilled one of the goals of the NMFS (1998) Recovery Plan for the shortnose sturgeon: to determine abundance, age structure, and recruitment for population segments. 


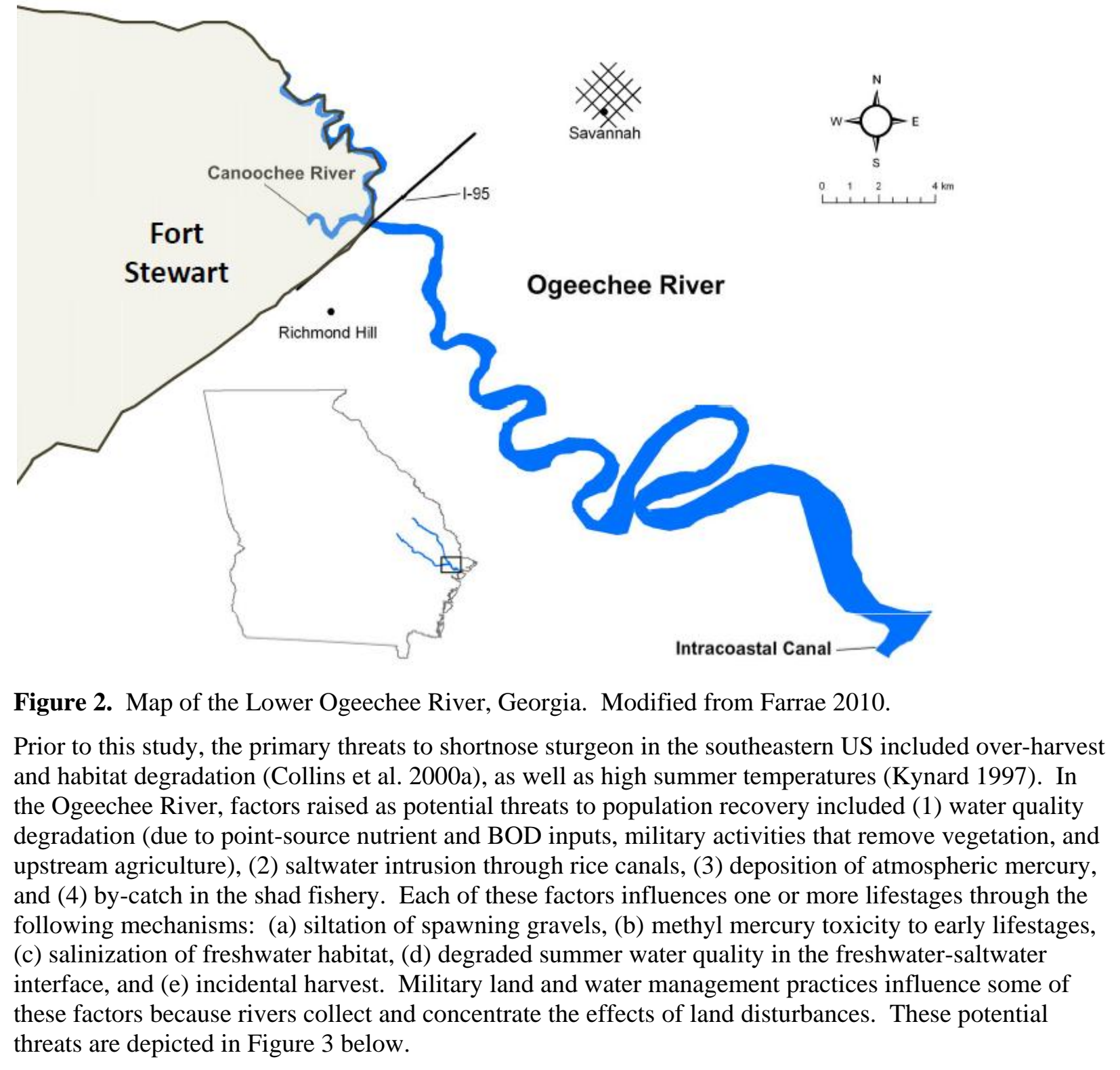




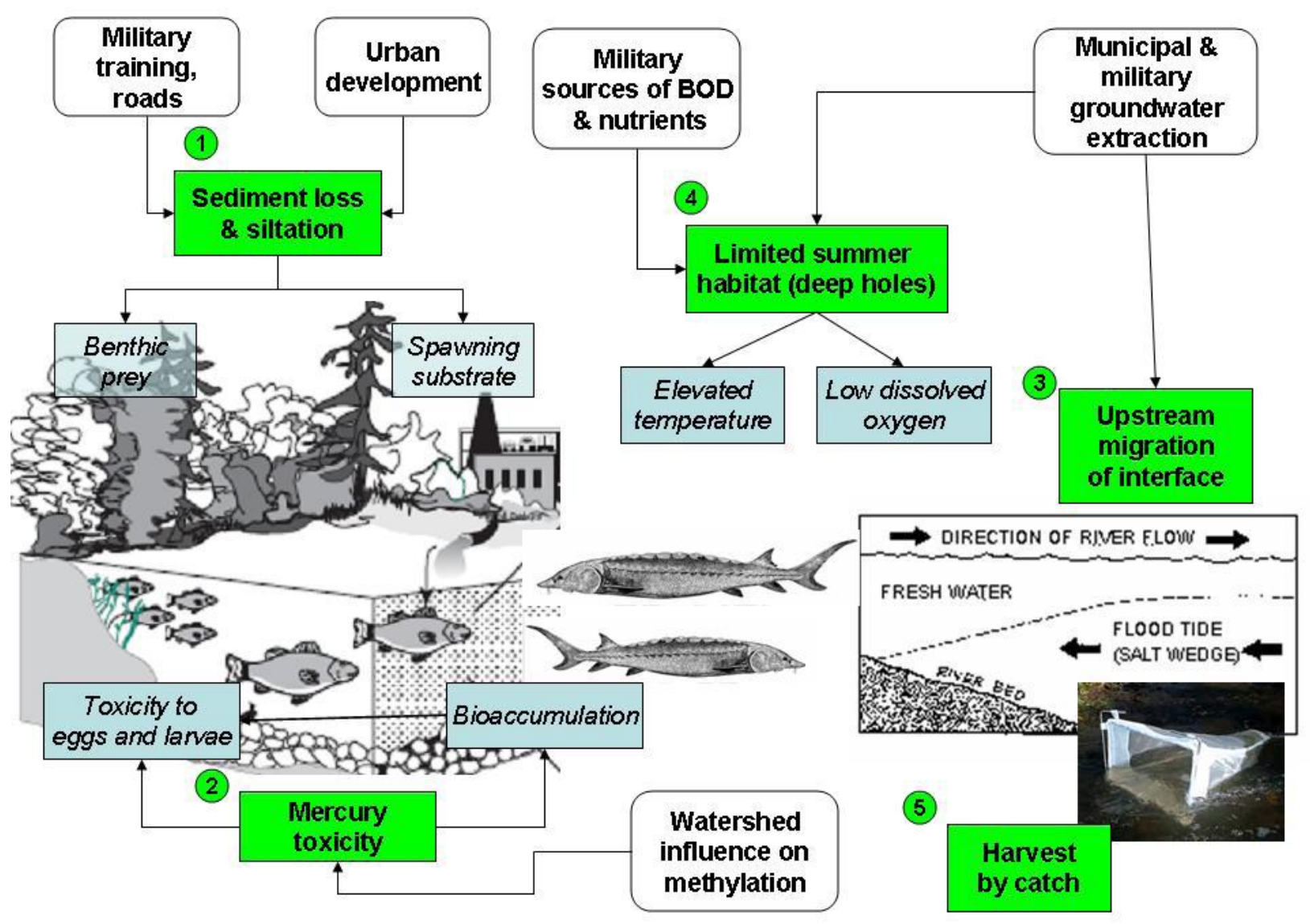

Figure 3. Hypothesized effects (blue) of potential threats (green) that might influence shortnose sturgeon recovery in the Ogeechee River.

PVA models can be used to forecast population sizes over time and the likelihood of population persistence into the future. If a mechanistic model is built that includes risk factors, such as those above, simulations can quantify the effects of various threats, alone and together. Below, we introduce the threats that were not eliminated early as a result of a workshop held early in the project. These correspond to the questions listed in the Objective section above.

Water quality - In Georgia, several rivers exhibit low oxygen levels $(<2.5 \mathrm{mg} / \mathrm{l})$ at the saltwater / freshwater interface, an area that normally aggregates both juveniles and adults (Rogers and Weber 1995). Increasing salinity and temperature decrease dissolved oxygen available for the shortnose sturgeon and other aquatic organisms. This is a particular concern in deeper waters inhabited by benthic organism like sturgeons. Consequently, river habitat with suitable water quality migrates inland during summer and during periods of low freshwater inflow. Shortnose sturgeon show signs of stress in water temperatures above $28^{\circ} \mathrm{C}$ (Kynard 1997, NMFS 1998). At these temperatures, concomitant low levels of DO may be lethal. Studies also show an age-related increase in salinity tolerance within the first year of life. Smith et al. (2002) suggested that age-0 sturgeon are more-susceptible to poor water quality in summer because they are less tolerant of low DO and high temperatures and because lack of salt-water tolerance restricts their access to estuarine habitat where water temperatures may be lower. This is a particular concern during drought conditions, when the interface between salt and fresh water shifts upstream. Poor water quality can significantly decrease food consumption and growth, one reason that southern populations of sturgeon tend to cease foraging and lose weight over the summer. 
Sediment-Hard bottom substrates are required for spawning by both Atlantic and shortnose sturgeon. Sturgeon eggs are adhesive, and if encapsulated by sand or silt, the developing egg is suffocated (Fox et al. 2000). Pre-larval sturgeon inhabit the interstitial spaces between coarse, hard substrates, where they are protected from predators and better able to resist drift (LaHaye et al. 1992). Thus, we expect an interaction between mortality associated with premature exposure to salinity and substrate. Fort Stewart would have a potential role in siltation of spawning grounds if the Canoochee River entered the larger Ogeechee River, where shortnose sturgeon are known to spawn, far enough upstream to have an impact. Fort Stewart may also be having an effect on sedimentation in the Canoochee River and in smaller tributaries, and therefore we investigated training effects on suspended sediment in headwaters.

Mercury-Methylmercury concentrations in water and biota throughout blackwater coastal streams in the Atlantic coastal plain are higher than those typical of riverine systems farther inland (Hughes et al. 2000, Bonzongo and Lyons 2004) and total and $\mathrm{MeHg}$ concentrations in the Canoochee River in Georgia ( 1.7 $\mathrm{ng} / \mathrm{L}$ ) are consistent with the high concentrations of $\mathrm{MeHg}$ accumulated in fish in that system (USEPA 2004). Mercury sources to the Canoochee/Ogeechee system are predominantly atmospheric deposition, runoff, and soil erosion (USEPA 2004). Blackwater streams tend to retain inorganic mercury in the water column and favor conversion of inorganic mercury to methylmercury because of their low $\mathrm{pH}$, high organic matter, and extensive aerobic/anaerobic interfaces (Morel et al. 1998). Methylmercury concentrations reported in USEPA 2004 for the Ogeechee River were nearly ten-fold higher than concentrations measured the nearby Savannah River system (Paller et al. 2004). High methylmercury concentrations in water and other fish species suggest that adult shortnose sturgeon could accumulate 0.5 to $1.0 \mathrm{mg} / \mathrm{kg} \mathrm{MeHg}$. A study by the USEPA (2004) to set TMDL limits on listed segments of the Canoochee River measured concentrations above $1.0 \mathrm{mg} / \mathrm{kg}$ in largemouth bass. Although at a lower trophic level, sturgeon likely accumulate $\mathrm{MeHg}$ by feeding on filter-feeding molluscs (Leaner and Mason 2002; Paller et al 2004), as evidenced by substantial MeHg bioaccumulation in other sturgeons (MacDonald et al. 1997, Alam et al. 2000, Buhler et al. 1973).

Harvest - Fishing mortality is considered by some to be an important threat to sturgeons in general, and southern shortnose populations in particular (Collins et al. 2000a). The recovery plan also lists fishing as a threat to shortnose sturgeon persistence (NFMS 1998). Because the shortnose sturgeon is an endangered species, harvest is not permitted, but they are vulnerable to the Atlantic sturgeon fishery and to be caught during spawning migrations by the shad fishery.

Extinction thresholds - PVA modeling can be used, not only to quantify threats to recovery, but also to identify extinction thresholds such as minimum viable population size (MVP) and minimum habitat. One goal of this study is to determine whether such thresholds can be identified to provide guidance to resource managers. 


\section{MATERIALS AND METHODS}

\section{SHORTNOSE-STURGEON WORKSHOP}

We conducted a workshop with the following objectives: 1) to assemble experts on shortnose sturgeon and the river's habitat, 2) to present our proposed project, 3) to solicit feedback on the proposed project from as many of the experts as possible, 4) to help modelers to develop a gestalt for this sturgeon species, its interactions with its physical habitat, and key human or military influences on the population, and 5) ask participants for feedback on whether to go forward with the project. The workshop was held February 5, 2007 at the Hampton Inn and Suites in the Historic District of Savannah, Georgia. We invited 27 people with expertise in areas related to our project, and 21 attended.

\section{PVA MODELING}

Two components of the PVA model are the dynamic simulation of habitat and the biological and demographic response by shortnose sturgeon. Below, we provide a brief summary.

Ogeechee River habitat. We implemented an option to use longitudinal and seasonal relationships for temperature and salinity. We developed a seasonal model for air temperature from historical climate data from the Savannah International Airport. We developed an empirical model for water temperature based on air temperature and flow (from USGS). We fitted a salinity relationship as a function of distance from ocean to data collection locations from a study by Alber and Sheldon (1999). The PVA model has been designed to import environmental drivers (flow and temperature) and to read habitat suitability information that will allow local water quality to influence habitat use and survival.

Shortnose sturgeon biology. Spawning migration and reproduction are simulated in late winter. Development of eggs is driven by temperature. Incubation survival is simulated as a function of temperature and local egg density. Natural age-related mortality was simulated, as was mortality due to starvation, exposure to poor water quality conditions (salinity for age-0 sturgeon, temperature, low DO), and incidental harvest as by-catch in the shad fishery.

We implemented two options for simulating sturgeon growth for juveniles and adults. First, a simpler (non-bioenergetic) growth routine was implemented using parameters for shortnose sturgeon from the literature, including age-growth, weight-length, and fecundity-weight relationships. Next, we implemented a bioenergetic growth and starvation mortality in the PVA model. A stand-alone bioenergetics model was developed. A modified version of this model that included prey dynamics was incorporated into the PVA model and calibrated against age-length relationships measured in the Ogeechee and Altamaha Rivers (Figure 4). 


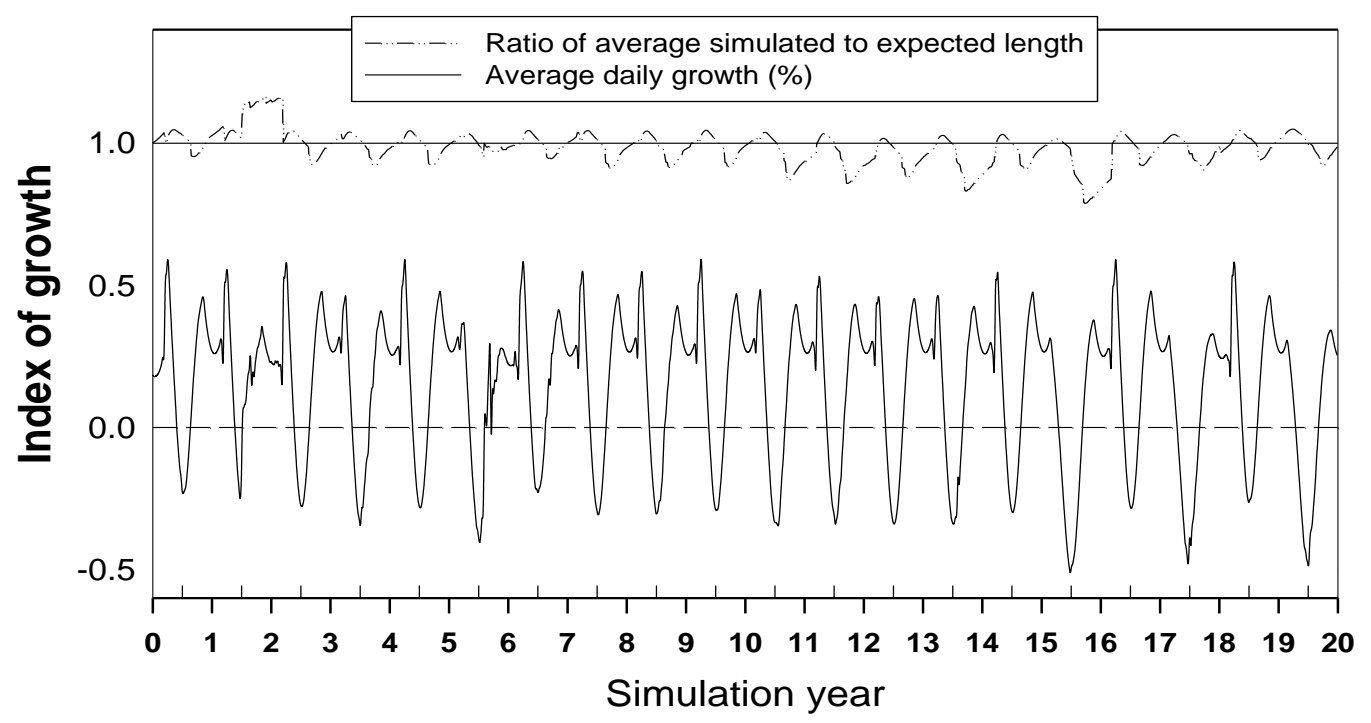

Figure 4. Simulated average daily growth in weight over twenty years showing positive growth in the winter and negative growth in summer (solid line). On the x-axis, years are labeled in winter ( Jan 1) and mid-summer is indicated by upward ticks. The ratio of simulated fish lengths to those expected based on field measurements fluctuated around the desired value of one (dash-dotted line).

Simulation experiments. We conducted simulation experiments to evaluate two extinction thresholds of interest: minimum viable population size (MVP) and minimum habitat. To estimate MVP, we simulated the Ogeechee River population with a range of initial population sizes and river lengths. We adopted an operational definition for MVP as the initial size for which at least $95 \%$ of replicate populations persisted. To evaluate habitat limitation, we compared persistence over 20 historical years using three different assumptions about where spawning occurred, at 83,100, and $125 \mathrm{~km}$ upstream.

Our second set of simulation experiments evaluated the individual and combined effects on persistence over 20 years in simulations with and without three causes of mortality: 1) poor water quality, 2) rice canals and saltwater intrusion, and 3) by-catch harvest for an initial population size of 225 individuals.

\section{MERCURY TOXICITY}

We developed a model to predict bioaccumulation of contaminants in adults, transfer to eggs, and early mortality associated with concentrations of mercury in amphipod prey in the saltwater-freshwater transition zone of the Ogeechee River and estuary. Our model requires estimates of 1) prey concentrations, 2) trophic exposure of shortnose sturgeon through several trophic pathways, 3) lifetime bioaccumulation by shortnose sturgeon in somatic and gonadal tissue, 4) transfer of contaminants to eggs and survival of eggs. We implemented the model in Stella to predict concentrations in shortnose sturgeon and eggs.

Our assessment of mercury as a threat to shortnose sturgeon, and particularly early lifestages, involved three sub-tasks. First, we developed a bioenergetics model capable of partitioning growth of somatic and gonadal tissue of an adult female shortnose sturgeon. Next, we added uptake of mercury from prey and partitioning of mercury between somatic and gonadal tissue (i.e., eggs). We measured concentrations of both methyl mercury and total mercury in amphipods collected in the freshwater-saltwater transition zone and of incidentally collected gonadal tissue collected while staging (assessing maturity of eggs) shortnose sturgeon. Finally, we compared model predicted estimates of egg mercury concentrations with those from our samples.

We developed a mercury uptake model to simulate change in the body burden and concentration of 
methyl mercury in a female shortnose sturgeon over time as a result of feeding on a diet with estimated prey concentrations. In addition, we estimated the concentration of methyl mercury in eggs produced by this female as an adult.

\section{Prey concentrations}

Shortnose sturgeon feed primarily on aquatic insects, crayfish and mollusks. Fish are occasionally eaten. Shortnose sturgeon are primarily, but by no means exclusively, benthic feeders with a diet that reflects the availability of different prey types in estuary, reservoir, and riverine habitats. In estuaries, shortnose sturgeon stomach contents are dominated by amphipod shrimp (Smith et al. 2002) and mollusks, particular species in the genus Corbicula. Amphipods were collected along a salinity gradient in the transition zone of the Ogeechee River during 2008. Concentrations of both total and methyl mercury were measured by Patrick Pang at Cebam Analytical.

Modeling mercury bioaccumulation.-One of our objectives was to simulate partitioning of contaminants between somatic and gonadal compartments. Mercury is not a lipophyllic compound, and redistribution of $\mathrm{MeHg}$ in fish tissue results in elevated concentrations in muscle tissue and lower concentrations in gonadal tissue (Weiner and Spry 1996, Webb et al. 2006). Latif et al. (2001) conducted experiments to study uptake of $\mathrm{MeHg}$ by females and transmitted to egg and larval stages of walleye (Stizostedion vitreum). Egg and larval concentrations were positively correlated with maternal muscle concentrations of MeHg. Mercury tends to bioaccumulate in sturgeons as they grow. Webb et al. (2006) also found a positive relationship between shortnose sturgeon length and mercury. Mercury concentrations among 89 lake sturgeon increased with length according to the relationship $\mathrm{Hg}(\mathrm{ppm})=-4.146+0.046$ Length $(\mathrm{cm})$.

We developed a bioenergetics model for shortnose sturgeon building on a bioenergetic model for white sturgeon (Bevelhimer 2002). The bioenergetics model was implemented both as a stand-alone model in STELLA $^{\mathrm{TM}}$, and incorporated, with modifications, in the PVA model. The bioenergetics model includes equations for consumption and storage of energy in somatic and gonadal compartments as a function of ration and temperature (Figure 5). Along with growth in these compartments, the model predicts the number and weight of eggs spawned.

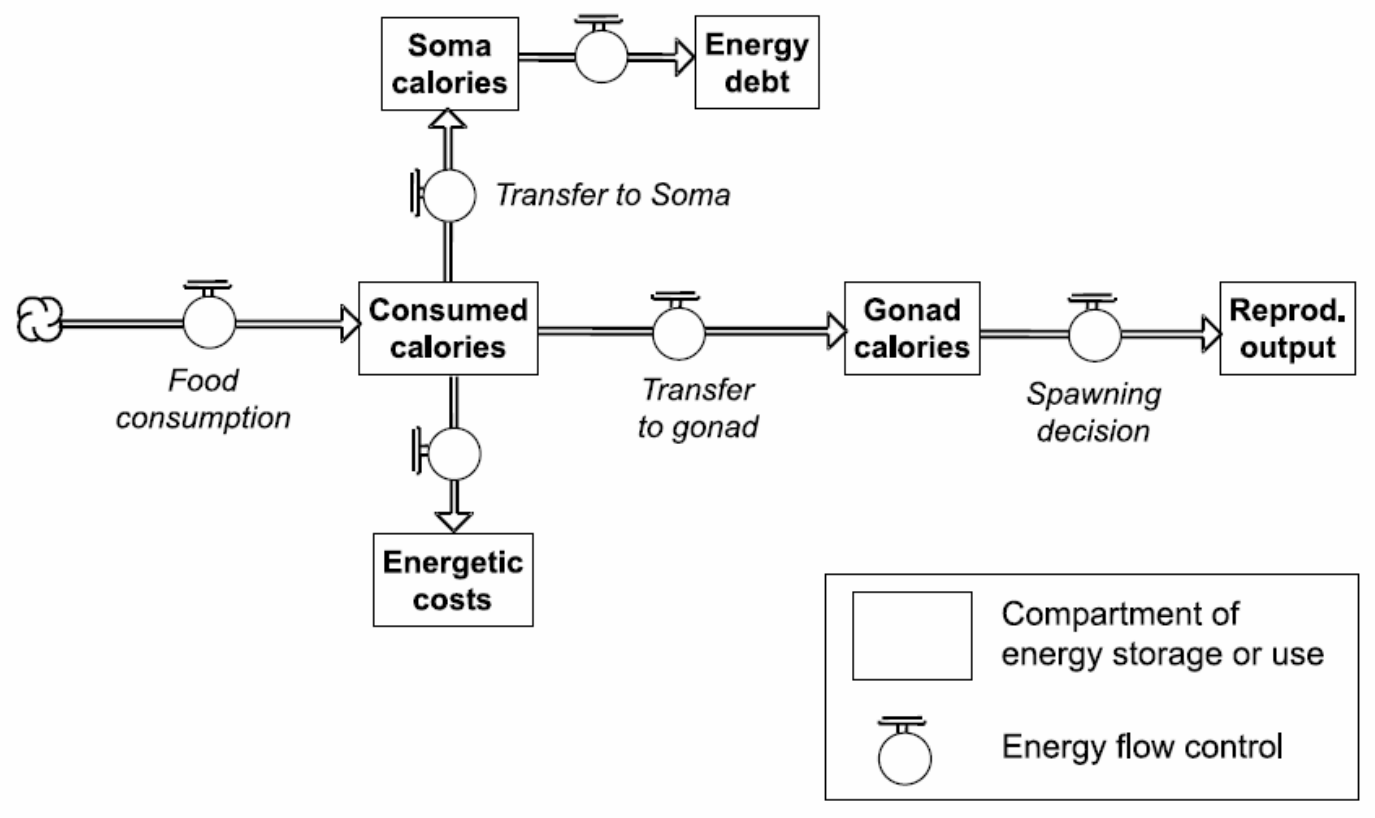

Figure 5. Diagramatic representation of energy allocation in the white sturgeon bioenergetic model of Bevelhimer (2002). 
To simulate bioaccumulation of mercury, we added new equations to simulate intake of prey with known contaminant concentrations. We implemented a modified version of the uptake model presented by Trudel and Rasmussen $(2001 ; 2006)$ that simulates the body burden of an adult female as the balance between contaminants gained through feeding and contaminant loss through elimination and egg deposition (Figure 6).

The somatic mercury burden of an adult female, $B s$, increases through feeding on contaminated prey at rate $P$, and decreases through elimination at rate $E$, and redistribution of mercury to gonadal tissue at rate $R$ (Equation 1).

$$
\frac{d B s}{d t}=P-(E+R) B s
$$

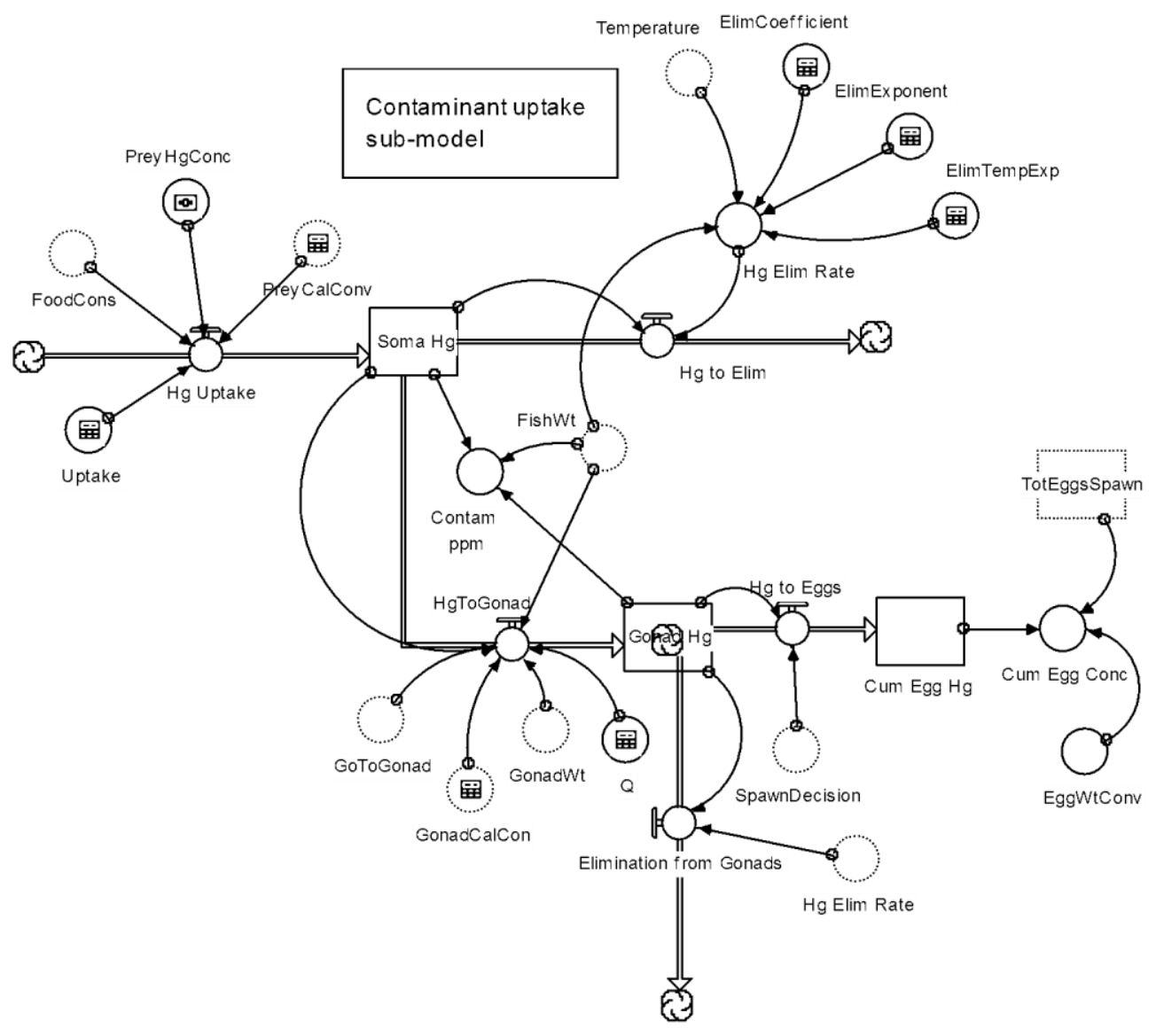

Figure 6. Stella ${ }^{\mathrm{TM}}$ model to simulate contaminant uptake. Dashed shapes are simulated stocks (boxes) and converters (circles) from the bioenergetics model.

Mercury intake.- The body burden of $\mathrm{MeHg}$ in fishes has been shown to accumulate primarily through feeding (Trudel and Rasmussen 2001). We track the body burden in somatic and gonadal tissue separately. The rate of mercury assimilation $(\mu \mathrm{g} / \mathrm{d})$, assimilated by a female shortnose sturgeon, is

$$
P=\alpha C_{\text {prey }} I
$$


where $\alpha$ is its uptake efficiency, $C_{\text {prey, }}$, is the concentration of mercury in prey ( $\mu \mathrm{g} / \mathrm{g}$ prey) and $I$ is the female's rate of prey consumption. Prey consumption is calculated as an allometric function of fish weight and temperature (Bevelhimer 2002).

\section{Mercury redistribution}

We simulate the redistribution of mercury from somatic to gonadal tissue. When the female sturgeon's surplus energy is sufficient to permit egg development the model shifts all surplus energy from somatic to gonadal tissue. Other conditions must also be met, for example, the female has to be old enough to spawn and wait a minimum time since a previous spawning event. The rate at which mercury in somatic tissue is redistributed, $\mathrm{R}$, per unit time is given by Equation 3 .

$$
R=\frac{Q}{W s} \Delta W
$$

where $Q$ is the ratio of mercury concentration in female gonadal tissue to its concentration in whole fish, $W s$ is the weight of somatic tissue (later used to convert $B s$ to a concentration), and $\Delta W$ is the rate of surplus energy gain, expressed in weight equivalents.

We used data from white sturgeon in the lower Columbia River to estimate $Q$. Mercury concentrations in white sturgeon were significantly higher in muscle $(170.54 \pm 12.67 \mathrm{ppb}, \mathrm{n}=57)$ and liver $(140.26 \pm 23.02$ $\mathrm{ppb}, \mathrm{n}=49)$ than in gonadal tissue $(27.26 \pm 2.50 \mathrm{ppb}, \mathrm{n}=49)$ (Webb et al. 2006). Our estimate of $Q=$ 0.16 for sturgeon is higher than the value of 0.12 estimated by Trudel and Rasmussen (2001) for fish in general. The Webb et al. sample did not include mature females (gonadosomatic index < 2), suggesting that a sample with older, ripe females with a high proportion of weight in gonadal tissue would yield a higher estimate of $Q$.

Another way that one might estimate $\mathrm{Q}$ would be to assume that the relative protein content of eggs vs. somatic tissue corresponds to its affinity for gonadal tissue. However, this approach did not yield a reasonable estimate because sturgeon eggs contained a higher (26.21 to $31.13 \% \mathrm{WW}$, Gessner et al. 2002), not lower, percent protein than the edible portion of cultured sturgeon [12-15\% WW, Beamish et al. 1996; 19.23\% (SD=0.17) WW, Badiani et al. 1996].

\section{Mercury losses}

Overall $\mathrm{MeHg}$ loss is simulated as the sum of the elimination rate and the loss of contaminants through egg deposition. Each of these losses is discussed below.

The elimination rate, $E$, is represented by a function of weight, $W$, and temperature, $T$,

$$
E=\varphi W^{\beta} e^{\lambda T} .
$$

This rate is applied to mercury in both the somatic and gonadal tissue. We adopted parameter estimates, $\varphi=0.0029, \beta=-0.20$, and $\lambda=0.066$, from a study by Trudel and Rasmussen (1997) that included data from a wide range of piscivorous fish species.

Because females spawn infrequently every ( 3 to 11 years), the loss of contaminants from gonadal tissue through egg deposition is simulated as an event-based, rather than a continuous, process. In years when a particular female shortnose sturgeon of weight $W$ spawns, the bioenergetics model determines how many calories of eggs she deposits, which is converted to grams, $W s$, by assuming 2,200 cal g ${ }^{-1}$ of eggs. The mercury in the gonadal compartment, $B g$, is also transferred to eggs (Equation 5). When the female does not spawn, mercury in gonadal tissue is gained through redistribution from somatic tissue and lost through elimination (Equation 5). 


$$
\frac{d B g}{d t}=\left\{\begin{array}{l}
Q\left(\frac{W s}{W}\right) B g, \text { if female spawns } \\
R \cdot B s-E \cdot B g, \text { if female does not spawn }
\end{array}\right.
$$

\section{Mercury simulations}

Water quality factors, such as temperature and low DO, are likely to influence growth and reproduction of shortnose sturgeon simulated by the Stella model. We simulated female body (soma) concentrations and egg concentrations using historical temperatures and flows recorded at three upstream gages on the Ogeechee, Canoochee, and Black Rivers. Simulations started with a 3-year-old with no prior exposure to mercury. We used the feeding ration calibrated to match shortnose sturgeon growth observed in the Ogeechee River. We simulated prey concentrations for the range of $\mathrm{MeHg}$ concentrations measured in amphipods from the Ogeechee's transition zone.

\section{WATER QUALITY}

Three components of this task were sampling the lower Ogeechee River, measuring water chemistry in the Canoochee River, which drains Fort Stewart, and implementing a water quality model. Summer water sampling was conducted weekly in the lower Ogeechee River between fall 2007 and late August 2009.

\section{River sampling}

Ogeechee.-In the lower Ogeechee River, surface and bottom temperature, salinity, and dissolved oxygen (DO) were measured bi-weekly between the spring of 2007 and late-summer 2009. These measurements were taken between Ogeechee River kms 20 and 80. We used these data to evaluate the risk to shortnose sturgeon and other aquatic biota of episodic low DO and to develop equations to estimate water quality parameters in the dynamic PVA model.

Canoochee.-The Canoochee River drains the majority of land on Fort Stewart and feeds into the tidal lower Ogeechee River at river km 55 (Figure 7). We collected water samples from two bridges on each of two branches of the Canoochee River and two bridges below the confluence, which is approximately in the center of the installation (Figure 7). We collected water samples from Bridges 27 and 28 on Canoochee Creek, which enters from the southwest, and Bridges 15 and 19 on the upper portion of the Canoochee River which flows in from the northwest, and from two downstream bridges on the mainstem (Figure 7). Bridge 15 is located at the point that the Canoochee River enters Fort Stewart. Bridge 19 is downstream of bridge 15 on the Canoochee River, upstream of the Canoochee Creek confluence. On the southwest fork, Canoochee Creek runs past Bridges 27 and 28 downstream of the confluence with Taylor Creek. A waste water treatment facility located on Taylor Creek supports both Fort Stewart and the city of Hinesville. Canoochee Creek joins the Canoochee River, and continues past a large training area to the north with large areas of bare ground and under Bridges 38 and 40 before joining the Ogeechee River (Figure 8).

The bridge farthest downstream, Bridge 40, experiences a small amount of tidal influence. Water samples collected at this point measure the influence of Fort Stewart activities, natural vegetation, and in-stream processes, as well as the inflows to the installation from Canoochee Creek and the upper portion of the Canoochee River. A DataSonde operated by Fort Stewart's Natural Resources Department at Bridge 40 measured dissolved oxygen at regular intervals.

We collected and analyzed water samples at bridges on the Canoochee River on two occasions: Once in August 29, 2008 and again August 12, 2009. The most significant difference between these two dates was that the 2008 samples were taken during the tail of tropical storm Faye, which occurred after a long period of drought, and the 2009 samples were taken in a week with no precipitation. Water chemistry measurements were the same for these samples as those described above for headwater stream samples. 
We conducted a separate analysis of Bridge 40 samples on three occasions to estimate the proportion of DOC likely to be converted to particulate organic matter (POC) in the saltwater-freshwater interface of the Ogeechee River. We used the same procedure as described earlier to prepare the DOC sample, except that we transferred a larger, 250-ml, portion to allow sufficient sample after DOC analysis for the flocculation experiment. Ocean water was collected at the "farewell" buoy of St Simons sound and, depending on tide, had salinities ranging from 25.7 to 34.5 ppt. Samples were diluted to achieve a salinity of around 3 ppt. After testing one subsample for DOC, ocean water was added to a second subsample. This sample was refrigerated and incubated for $24 \mathrm{~h}$. We estimated POC as the decrease in DOC in the subsample with ocean water added relative to DOC in the original river water sample.

\section{River modeling}

We developed two approaches to modeling three water quality variables (salinity, temperature, DO) in the river occupied by shortnose sturgeon. These are described below.

Empirical models-Based on these measurements, we used empirical relationships developed for temperature, salinity, and DO in the PVA model for historical simulations. In addition to previous linear models, we sought a DO model with quadratic terms for salinity and/or river $\mathrm{km}$. Taking the derivative and solving this could then be used to identify the location or salinity where DO is at a minimum. Although the quadratic terms were significant with minimum DO at and below the Canoochee confluence, the relationships were weak.

Numerical model - In addition, we implemented the hydrodynamic component of the Environmental Fluid Dynamics Code (EFDC). The EFDC hydrologic model now simulates temperature and salinity in the Ogeechee and lower Canoochee Rivers. Before the PVA model could be used for future projections with different climate conditions, the water quality aspects of EFDC would need to be implemented and linked with the PVA. 


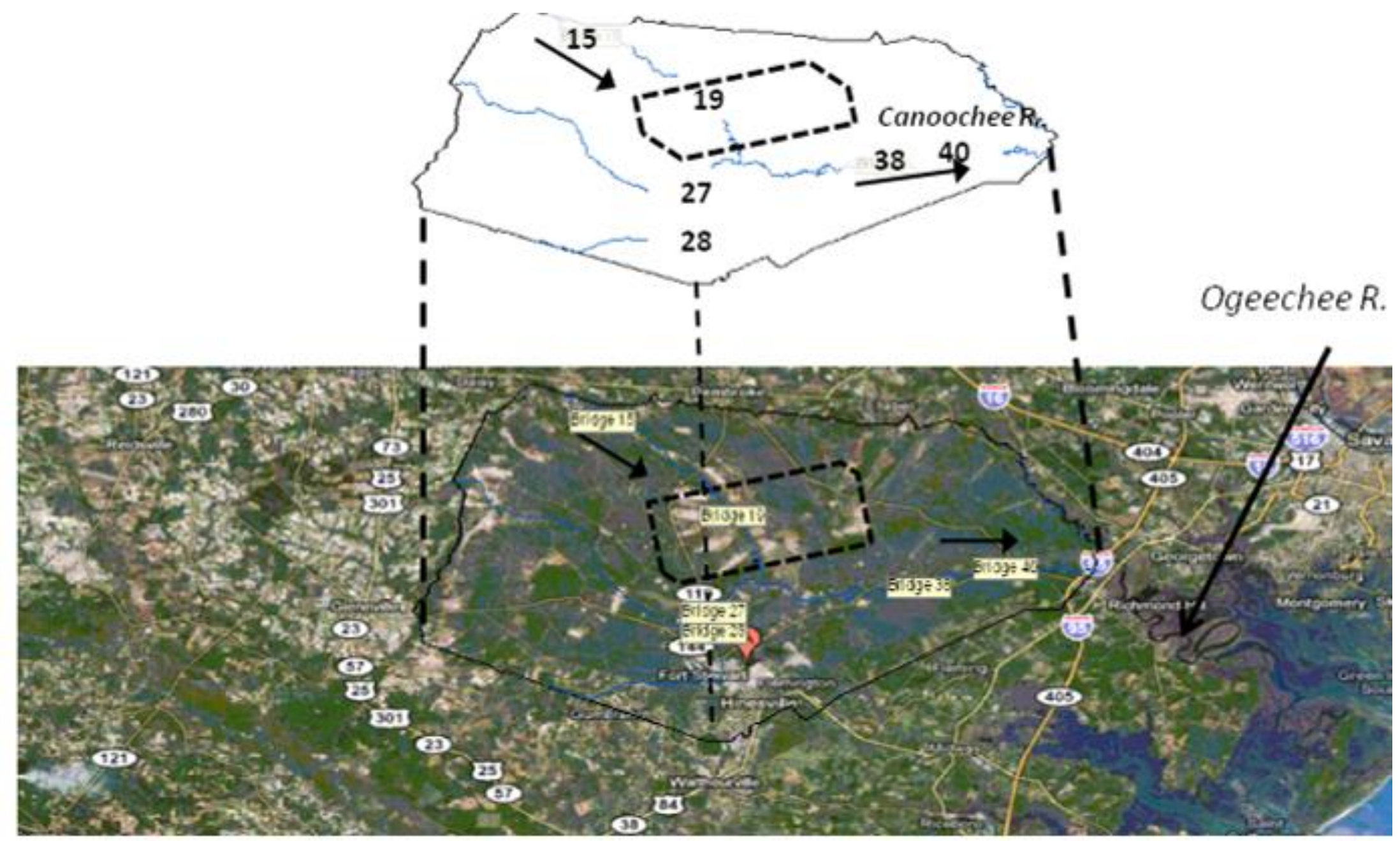

Figure 7. Schematic map of bridge sample locations overlaid on a Google satellite map that indicates barren training areas (dotted outline) on Fort Stewart. Note also the contrast between developed areas surrounding Fort Stewart and the amount of forested and other less-developed land within the installation boundaries. 


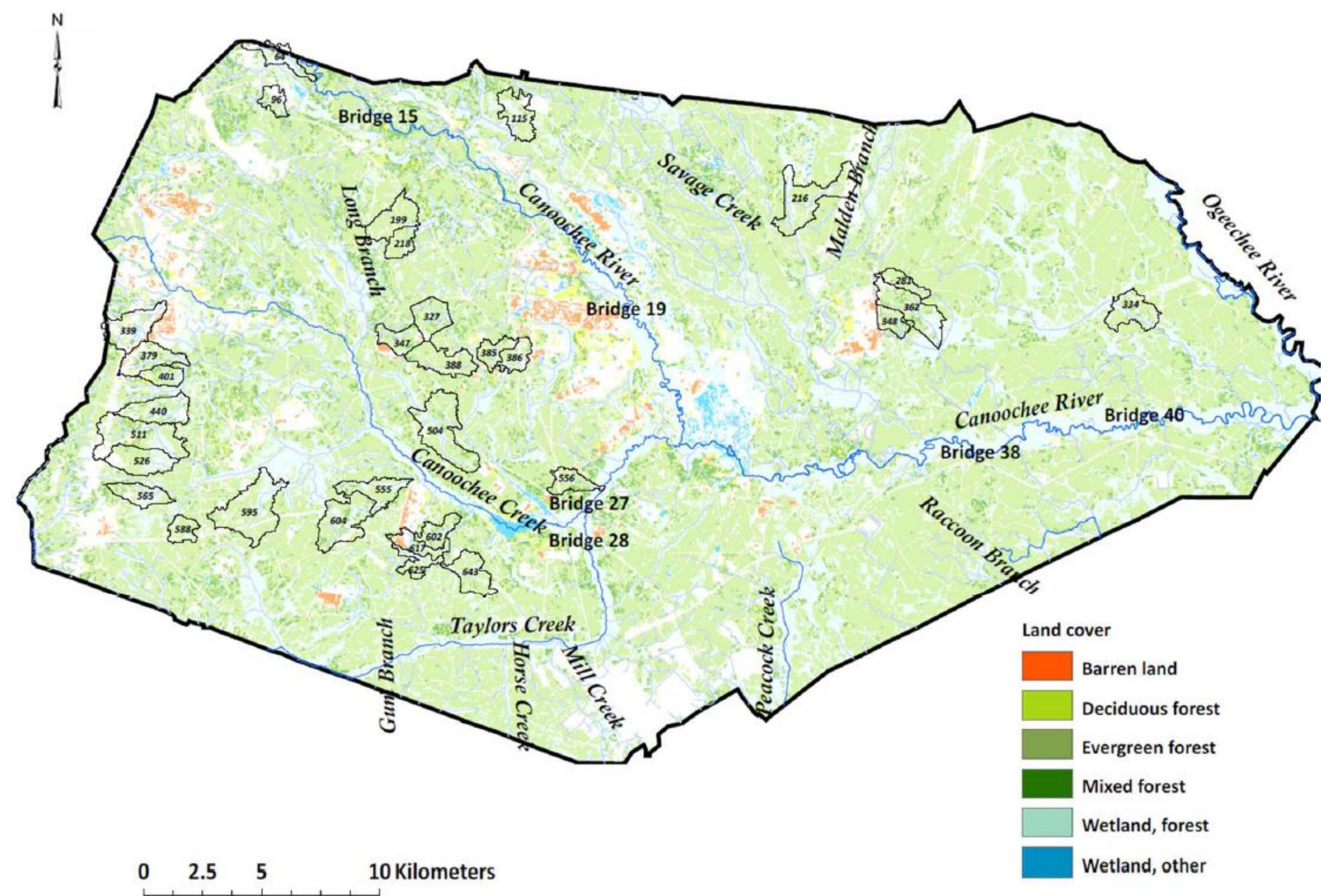

Figure 8. Accessible, headwater watersheds included in our sample in the western portion of Fort Stewart, Georgia. Watershed id's refer to those in Table 1. 


\section{WATERSHED ASSESSMENT}

\section{Watershed sampling design}

Our study focused on headwater drainages, which are desirable for detecting the influences of watershed cover and training activities. Therefore, we selected as our sampling unit drainages of roughly 200 ha on a 1:50,000 map. We used the Soil and Water Assessment Tool (Gassman et al. 2007), with elevation and stream data, to delineate watersheds within Fort Stewart's boundaries that ultimately drain to the Canoochee River. We used ARCGIS (ESRI, Redlands, CA) to identify and exclude non-headwater watersheds, watersheds in inaccessible training areas (in the eastern half of the installation), poorlydelineated watersheds and watersheds lacking blue-line streams (wetland-dominated areas), watersheds on the Fort Stewart boundary not draining to the Canoochee River, and those draining to Taylor Creek (Figure 8). Taylor Creek drainages were excluded because two point sources entering Taylor Creek would overwhelm watershed influences. Our final list frame included 45 accessible headwater watersheds in the western half of Fort Stewart (all watersheds in Table 1).

The primary purpose of this design was to provide data needed to develop good empirical models (Ator et al. 2003). Two problems that often plague modeling efforts can be addressed at the sample selection stage are too little variability among important predictors and multicollinearity among predictors. To address these issues, we developed a method with two goals: 1) to minimize correlation between the predictors and 2) to include watersheds with extreme values of anticipated predictors. For each accessible headwater watershed, we characterized watershed attributes that we expected $a$ priori to predict differences in water quality including percent wetland, forest, and bare ground. To ensure that extremes were included in the sample, we defined strata based on the $25^{\text {th }}$ and $75^{\text {th }}$ quartiles of these three variables and sampled equally from each quartile. We developed a method for minimizing correlation among watershed attributes within the sample. We drew 100 stratified samples of 25 watersheds from the list frame of 45 watersheds and calculated the maximum absolute pairwise correlation for each sample. We then retained the sample with the lowest maximum (candidate watersheds in Table 1). Among the samples drawn, the maximum absolute correlation was 0.73 and the minimum (candidate sample) was 0.45. A site visit was conducted to choose 20 watersheds for instrumentation. Although 15 watersheds were selected from the candidate sample (history code $=3$ in Table 1), 5 watersheds were not from the list of candidate watersheds (history code $=1$ in Table 1). This deviation from the protocol ensured that samples from all 20 sites could be accessed within a half-day. Water quality samples were taken at the outlets of all 20 watersheds in summer of 2008. After this first sampling date, we decided to relocate four of the sites to the outlets of alternative watersheds because water levels in these four streams were so low. These flows may have been atypical during mid-summer, 2008, which ended a multi-year drought in the southeast. Three suitable alternatives were identified and sampled in subsequent efforts (designated by "B" in Table 1), and the fourth was relocated to a non-headwater site not included in our analysis. 
Table 1. List frame of accessible headwater watersheds on Fort Stewart and subsets representing those sampled. Lab ids in column 1 with ' $A$ ' appended indicate sites replaced after 2008, and replacement sites are indicated by a 'B'. History codes indicate headwater accessible watersheds in list frame: $0=$ not in candidate sample, not sampled; $1=$ not in candidate sample, sampled; $2=$ candidate sample, not sampled (excluded during site visit); $3=$ candidate sample, sampled.

\begin{tabular}{|c|c|c|c|c|c|c|c|c|c|}
\hline $\begin{array}{l}\text { Watershed } \\
\text { id (Lab id) }\end{array}$ & $\begin{array}{l}\text { History } \\
\text { code }\end{array}$ & $\begin{array}{l}\text { Training } \\
\text { area }\end{array}$ & $\begin{array}{l}\text { Road } \\
\text { density } \\
\text { (ha) }\end{array}$ & $\begin{array}{l}\text { Barren } \\
(\%)\end{array}$ & $\begin{array}{l}\text { Wetland } \\
(\%)\end{array}$ & $\begin{array}{l}\text { Grass } \\
(\%)\end{array}$ & $\begin{array}{l}\text { Forest } \\
(\%)\end{array}$ & $\begin{array}{l}\text { Months } \\
\text { since } \\
\text { burn }\end{array}$ & $\begin{array}{l}\text { Area } \\
\text { (ha) }\end{array}$ \\
\hline $64(1)$ & 3 & F-13 & 12.9446 & 0 & 49 & 12 & 34 & 19 & 164 \\
\hline 66 & 0 & F-12 & 23.7424 & 0 & 15 & 21 & 49 & 23 & 390 \\
\hline 69 & 0 & F-12 & 48.8100 & 0 & 14 & 17 & 54 & 25 & 137 \\
\hline $96(2)$ & 3 & F-12 & 31.2324 & 0 & 9 & 33 & 46 & 26 & 105 \\
\hline 101 & 0 & F-19 & 9.1005 & 0 & 36 & 7 & 54 & 28 & 264 \\
\hline $115(5)$ & 1 & F-19 & 16.0025 & 0 & 30 & 3 & 58 & 37 & 227 \\
\hline 117 & 0 & F-15 & 21.9184 & 0 & 30 & 8 & 50 & 24 & 256 \\
\hline 141 & 0 & F-18 & 12.9515 & 0 & 29 & 4 & 62 & 35 & 199 \\
\hline 147 & 0 & F-19 & 20.1080 & 4 & 28 & 36 & 20 & 30 & 114 \\
\hline 186 & 0 & F-16 & 10.5175 & 0 & 13 & 3 & 80 & 34 & 111 \\
\hline 199 (3) & 3 & F-6 & 13.7667 & 0 & 12 & 7 & 79 & 27 & 249 \\
\hline 216 & 2 & $\mathrm{C}-1$ & 16.9245 & 0 & 24 & 10 & 58 & 26 & 436 \\
\hline $218(4)$ & 3 & F-6 & 17.4024 & 0 & 12 & 1 & 82 & 21 & 126 \\
\hline 244 & 0 & B-12 & 9.5701 & 0 & 49 & 21 & 23 & 9 & 175 \\
\hline 255 & 0 & F-8 & 22.4441 & 0 & 5 & 3 & 85 & 25 & 144 \\
\hline 281 & 2 & B-19 & 27.2529 & 0 & 5 & 7 & 79 & 25 & 110 \\
\hline 298 & 0 & E-19 & 25.1825 & 0 & 18 & 15 & 55 & 25 & 110 \\
\hline $327(20 B)$ & 3 & F-4 & 11.0074 & 0 & 20 & 1 & 76 & 42 & 202 \\
\hline 334 & 2 & C-14 & 12.0085 & 0 & 29 & 4 & 64 & 32 & 243 \\
\hline 339 (16) & 3 & E-19 & 26.3872 & 5 & 17 & 33 & 26 & 28 & 297 \\
\hline 347 (6) & 1 & F-4 & 23.9496 & 2 & 12 & 8 & 71 & 43 & 163 \\
\hline
\end{tabular}




\begin{tabular}{|c|c|c|c|c|c|c|c|c|c|}
\hline $\begin{array}{l}\text { Watershed } \\
\text { id (Lab id) }\end{array}$ & $\begin{array}{l}\text { History } \\
\text { code }\end{array}$ & $\begin{array}{l}\text { Training } \\
\text { area }\end{array}$ & $\begin{array}{l}\text { Road } \\
\text { density } \\
\text { (ha) }\end{array}$ & $\begin{array}{l}\text { Barren } \\
(\%)\end{array}$ & $\begin{array}{l}\text { Wetland } \\
(\%)\end{array}$ & $\begin{array}{l}\text { Grass } \\
(\%)\end{array}$ & $\begin{array}{l}\text { Forest } \\
(\%)\end{array}$ & $\begin{array}{l}\text { Months } \\
\text { since } \\
\text { burn }\end{array}$ & $\begin{array}{l}\text { Area } \\
\text { (ha) }\end{array}$ \\
\hline 348 & 2 & B-19 & 20.9766 & 5 & 11 & 7 & 71 & 36 & 121 \\
\hline 362 & 2 & B-19 & 8.6118 & 0 & 27 & 7 & 63 & 36 & 353 \\
\hline 364 & 0 & E-11 & 62.7127 & 23 & 24 & 29 & 5 & 29 & 160 \\
\hline 379 (17) & 3 & E-16 & 56.0612 & 3 & 21 & 20 & 43 & 25 & 240 \\
\hline $385(20 \mathrm{~A})$ & 1 & F-2 & 26.0140 & 0 & 8 & 8 & 77 & 34 & 130 \\
\hline 386 (19) & 3 & $\mathrm{~F}-2$ & 43.8582 & 2 & 12 & 10 & 59 & 27 & 128 \\
\hline 388 (9B) & 1 & F-3 & 12.4118 & 0 & 9 & 4 & 83 & 51 & 259 \\
\hline 401 (13) & 3 & E-16 & 0.1292 & 0 & 23 & 7 & 67 & 24 & 124 \\
\hline 423 & 0 & E-16 & 17.9836 & 0 & 29 & 17 & 46 & 25 & 253 \\
\hline 433 & 0 & F-1 & 28.9074 & 0 & 21 & 9 & 58 & 21 & 109 \\
\hline 440 (14) & 3 & E-16 & 28.0448 & 0 & 29 & 16 & 50 & 20 & 269 \\
\hline $504(7)$ & 3 & F-2 & 6.9816 & 0 & 25 & 1 & 72 & 25 & 470 \\
\hline $511(18)$ & 3 & E-14 & 32.4106 & 0 & 24 & 14 & 54 & 26 & 461 \\
\hline $526(12)$ & 3 & E-14 & 22.1880 & 0 & 29 & 12 & 54 & 21 & 271 \\
\hline $555(11 \mathrm{~B})$ & 3 & E-6 & 24.7788 & 0 & 25 & 4 & 65 & 27 & 222 \\
\hline 556 & 2 & B-8 & 27.0620 & 1 & 10 & 3 & 76 & 36 & 149 \\
\hline 559 & 0 & E-13 & 35.4104 & 0 & 25 & 10 & 55 & 24 & 200 \\
\hline 561 & 0 & E-7 & 28.3344 & 0 & 29 & 0 & 63 & 22 & 104 \\
\hline $565(15)$ & 1 & E-13 & 1.9474 & 0 & 34 & 10 & 56 & 21 & 174 \\
\hline 569 & 0 & B-8 & 26.6425 & 2 & 7 & 16 & 65 & 29 & 132 \\
\hline 588 & 2 & E-13 & 42.5639 & 0 & 16 & 1 & 71 & 22 & 111 \\
\hline 592 & 0 & B-8 & 19.2748 & 0 & 20 & 15 & 56 & 21 & 415 \\
\hline 595 & 2 & E-7 & 34.9800 & 0 & 24 & 6 & 63 & 29 & 498 \\
\hline
\end{tabular}




\begin{tabular}{|r|r|l|l|r|r|r|r|r|r|}
\hline $\begin{array}{r}\text { Watershed } \\
\text { id (Lab id) }\end{array}$ & $\begin{array}{l}\text { History } \\
\text { code }\end{array}$ & $\begin{array}{l}\text { Training } \\
\text { area }\end{array}$ & $\begin{array}{l}\text { Road } \\
\text { density } \\
(\text { ha) }\end{array}$ & $\begin{array}{l}\text { Barren } \\
(\%)\end{array}$ & $\begin{array}{l}\text { Wetland } \\
(\%)\end{array}$ & $\begin{array}{l}\text { Grass } \\
(\%)\end{array}$ & $\begin{array}{l}\text { Forest } \\
(\%)\end{array}$ & $\begin{array}{l}\text { Months } \\
\text { since } \\
\text { burn }\end{array}$ & $\begin{array}{l}\text { Area } \\
\text { (ha) }\end{array}$ \\
\hline $602(8)$ & 3 & E-3 & 3.2632 & 0 & 25 & 1 & 73 & 36 & 143 \\
\hline $604(10)$ & 3 & E-7 & 49.3029 & 0 & 10 & 6 & 67 & 25 & 364 \\
\hline 617 & 2 & E-3 & 8.1777 & 11 & 24 & 19 & 43 & 33 & 136 \\
\hline 619 & 0 & E-4 & 17.4304 & 0 & 23 & 2 & 69 & 32 & 338 \\
\hline $625(11 \mathrm{~A})$ & 3 & E-3 & 43.5642 & 0 & 16 & 1 & 63 & 31 & 122 \\
\hline $643(9 \mathrm{~A})$ & 1 & E-3 & 24.1218 & 0 & 10 & 1 & 76 & 32 & 226 \\
\hline
\end{tabular}


Water samples were collected by hand under base-flow conditions and using rising-stage samplers for rain events. Rising-stage samplers were installed at the outlets of twenty watersheds to capture chemistry during rain events. Water samples were collected on August 22, 2008 following Hurricane Faye (4.923 $\mathrm{cm}$ rainfall) and December 12, 2008 (0.4191 cm rainfall). Water samples were collected manually on four other occasions, one following a rain and three under base-flow conditions. For the samples collected manually on May 7, 2009, $0.83 \mathrm{~cm}$ antecedent rainfall was recorded across five stations on Fort Stewart. Base flow samples were collected manually in spring of 2009 (February 12, March 30, and June 16).

Samples were all collected on the same half day, stored on ice and transported to the laboratory for filtration sub-sampling, and storage prior to analysis. Samples collected August 29, 2008 and all samples collected in 2009 were filtered within one day. The August 22 and December 12, 2008 collections were stored on ice for two days before processing. Water samples were analyzed for the following analytes: total suspended solids (TSS, mg L $\mathrm{L}^{-1}$ ), total organic carbon (TOC, $\mathrm{mg} \mathrm{L}^{-1}$ ), dissolved organic carbon (DOC, mg C L ${ }^{-1}$ ), total nitrogen ( $\mathrm{TN}, \mathrm{mg} \mathrm{N} \mathrm{L}^{-1}$ ), nitrate $\left(\mathrm{NO}_{3}, \mathrm{mg} \mathrm{N} \mathrm{L}^{-1}\right)$, ammonium $\left(\mathrm{NH}_{4}{ }^{+}, \mathrm{mg} \mathrm{N} \mathrm{L}^{-1}\right.$ ), total phosphorus (TP, $\mathrm{mg} \mathrm{P} \mathrm{L}^{-1}$ ), and soluble reactive phosphate (SRP, $\mathrm{mg} \mathrm{P} \mathrm{L}^{-1}$ ). DOC, and TOC, and TN were not measured for the February 2009 samples due to concern about holding times.

Fort Stewart base samples were collected in $1.5 \mathrm{~L}$ acid-washed $(10 \% \mathrm{HCl})$ polypropylene containers. Fort Stewart event samples were collected in 2 separate 1-L acid-washed polypropylene containers and mixed in an acid-washed 2-L container prior to sub-sampling.

These samples were delivered to a University of Georgia, Marine Extension laboratory in Brunswick, Georgia. Three unfiltered 125-ml subsamples were transferred into pre-washed amber glass bottles with Teflon-lined open-cap tops. The contents of two bottles were acidified. All unfiltered samples were frozen until analysis. An Apollo 9000 analyzed acidified samples for TN (high-temperature catalytic oxidation with chemi-luminescent detection) and TOC (sparge-combustion). The non-acidified sample was analyzed for TP using the ascorbic acid-molybdenum blue method (QuickChem method 31-115-013-A; Lachat, Inc. 1998).

Samples were filtered for analysis of dissolved nutrients and carbon (125-ml samples through $0.45 \mu \mathrm{m}$ filter). Those to be used for $\mathrm{N}$ and $\mathrm{P}$ analysis were frozen in polypropylene bottles, whereas those intended for DOC analysis were refrigerated in amber-glass bottles. SRP concentration was determined using the ascorbic acid-molybdenum blue method (QuickChem method 31-115-01-3-A; Lachat, Inc. 1998). We measured $\mathrm{NO}_{3}$ concentration using cadmium reduction of nitrate, followed by azo-dye colorimetry (QuickChem method 31-107-04-1-C; Lachat, Inc. 1999). Ammonium concentration was determined by phenate colorimetry (QuickChem method 31-107-06-1-E; Lachat, Inc. 1994). The remaining unfiltered sample was used for analysis of TSS. TSS concentrations were determined gravimetrically on $200-\mathrm{ml}$ subsamples filtered using $0.45-\mu \mathrm{m}$ filters. TSS mass was determined using a Sartorius analytical balance after drying for $2.5 \mathrm{~h}$ at $105^{\circ} \mathrm{C}$.

After receiving measurement results from the laboratory, ORNL conducted quality assurance checks on the data to ensure that the sum of constituents did not exceed total values. DOC represented a very high percentage of TOC, and in a few cases, slightly exceeded TOC. As another check, we compared total inorganic $\mathrm{N}$ with TN. We removed one high $\mathrm{NH}_{4}{ }^{+}$measurement that exceeded $\mathrm{TN}$ from our analyses for $\mathrm{NH}_{4}{ }^{+}$and organic nitrogen $(\mathrm{ON})$, which is calculated by difference.

\section{Fort Stewart land cover and land use}

Modeling land use and military training influences required us to characterize spatial attributes of watersheds on Fort Stewart. We summarized land-use and land cover (LULC) watershed attributes used as potential predictors, including percentages of various land cover types, time since last managed burn (months prior to 1-1-2008), length of road (m), and a variety of variables measuring training activity in a watershed. Area (ha) of land cover in each watershed was characterized by the 2001 National Land 
Cover Database (Homer et al. 2004) for four dominant cover types: 1) barren, 2) forest, 3) grassland, and 4) wetland. Road length (m) was calculated using GIS methods, where all roads except for the main highway on Fort Stewart are unpaved. We defined the following LULC predictors in models for stream chemistry, percent forest (Forest), percent grassland (Grassland), percent wetland (Wetland), time since burn (Burn), and the sum of percent barren and road density $($ Bare $+R d)$.

Fort Stewart is partitioned into training areas that completely cover the installation. We assessed training intensity by summarizing the scheduling of training areas for two types of activities: heavy equipment training (Equipment) and use of off-road vehicles (Tanks). We used average number of hours that training areas were reserved for each of these training activities over the years 2001 to 2005 as recorded in the Range Facility Management Support System, RMFSS database maintained by Fort Stewart. The RFMSS data were consistent with an independent survey of use filled out by two individuals familiar with training activities on the installation.

\section{Empirical modeling}

We developed empirical models for water quality measurements as functions of watershed attributes described in section 6.2 above. Response variables were $\log _{\mathrm{e}}$ transformed concentrations of TSS, TOC, DOC, TN, $\mathrm{NO}_{3}$ (defined here to include both $\mathrm{NO}_{3}$ and $\mathrm{NO}_{2}$ ), $\mathrm{NH}_{4}{ }^{+}, \mathrm{TP}$, and SRP in units of $\mathrm{mg} \mathrm{L}^{-1}$ incremented by one.

We identified predictors based on previous studies and expected responses. Most predictor variables that we included were static watershed attributes characterizing land cover (ha), military training activity, and months since burning. We expected an increase in TSS and possibly other analytes in response to military training activities in a watershed, linear meters of road, and barren area (Houser et al. 2006). We included wetland area because wetlands often reduce levels of sediment and inorganic nutrients, but can increase organic nitrogen and carbon. Antecedent rainfall and growing season both varied over time, but not space. We quantified antecedent rainfall, Rainfall in $\mathrm{cm}$, by summing the total spatially-averaged daily rainfall for all dates between the last date of dry weather (zero rainfall) and the date of sample collection, inclusive. Each date's total rainfall represents an average of five locations on Fort Stewart. The second predictor is an indicator variable, GrSeason, which was set to one for samples taken during the growing season (April - October) and to zero for winter samples.

We considered a class of linear mixed models with two components, one for fixed effects and one for error structure (random component). The random component allowed us to account for spatial and temporal dependence among samples. Following the recommendation of Zuur et al. (2009), we incorporated temporal covariates (Rainfall, GrSeason) into the fixed component of the mixed models. For the random component of the model, we considered models with different error variance for sampling date and Event, and we considered models with and without correlation from samples collected from the same watershed.

For each analyte, we followed the approach described by Zuur et al. (2009, p.120-122) for selecting among alternative mixed models. Mixed models include both a random and a fixed component. The Zuur et al. procedure begins by setting the fixed component of the model to include all predictors ("global" model) and comparing alternative random components. After selecting the global model producing the lowest Akaike's information theoretic criterion (AICc), we compared reduced fixed-effect models fitted using maximum likelihood. These were implemented using R's gls ('nlme' package, Pinheiro and Bates 2000) and aicctab ('AICcmodavg' package).

Burnham and Anderson (2002) recommend proposing and comparing candidate models, each a subset of the full model, including only predictors reasonably expected to have an influence. Our goal was to identify a subset of models supported by Akaike's Information Criterion,

$A I C c=2 L L+2 k+\frac{2 k(k+1)}{n-k-1}$, where $L L$ is the log-likelihood of a candidate model given the data, 
$k$ is the number of parameters fitted, and $n$ is sample size. Choosing models supported by AICc balances the need for additional predictors to achieve a close fit against the need for a robust, parsimonious model that will generalize to explain patterns in new datasets (Burnham and Anderson 2002). We present model weights for each of $k$ models, $w_{k}=\frac{e^{-A I C c_{k}}}{\sum_{i} e^{-A I C c_{i}}}$.

We compared the global fixed model with each of six error models using AICc for parameters fitted by restricted maximum likelihood (REML). Six error models considered were 1) errors independent and equal variance, 2) errors correlated within watershed and equal variance, 3) errors correlated within watershed and variance different for event samples, 4) errors uncorrelated and variance different for event samples, 5) errors correlated within watershed and variances by sampling date, and 6) errors uncorrelated and variances by sampling date. In general, we selected the error model with the lowest AICc, but if the error model included watershed correlation and the correlation was estimated to be negative, we selected the next-best model with no correlation assumed or estimated.

We compared all reasonable models involving subsets of the nine predictors. Because watershed influences of LULC predictors often depend on rainfall, we also considered a candidate model adding relevant interactions between LULC predictors and rainfall for those LULC predictors retained in the best-supported models (rainfall was always kept). We identified sets of supported models based on AICcderived model weights. We find these weights to be intuitively useful. In addition, models are considered to have information-theoretic support if the difference in AICc ( $\triangle \mathrm{AICc})$ between the model of interest and the minimum-AICc model is low (substantial support: $\triangle \mathrm{AICc}<2$, moderate support $4<$ $\triangle \mathrm{AICc}<7$, low support $\triangle \mathrm{AICc}>10 ;$ p. 170 Anderson 2008). We present full tables of model sets for five analytes with models having better predictive capability (TSS, TOC, DOC, TN and ON). Because AICc is a relative comparison of models, we present goodness-of-fit statistics for the model with the lowest AICc statistics and for the global model.

\section{SEDIMENTATION}

Our original research plan was to characterize sediment at spawning sites identified by Dr. Doug Peterson (UGA) and Daniel Farrae using telemetry, with the goal of evaluating effects on egg viability. The telemetry approach did not succeed because of the small number of adults tagged and failure to observe upstream movements during the year that the telemetry array was in place.

Because our efforts at telemetry did not succeed in identifying substrates suitable for shortnose sturgeon spawning, UGA provided results of an ongoing side-scan sonar analysis for the Ogeechee River. Note that the primary goal of this study was to evaluate spawning habitat for Atlantic sturgeon, which are also in this river system. The recent introduction of recreational multi-beam side-scan sonar equipment allows low cost and rapid acquisition of bathymetric data and substrate imagery in any navigable stream. However, utilization of this data is hindered by a lack of established protocols for processing and classification. Dr Nibbelink supervised a Masters student, John Hook, who worked with Thom Litts and Adam Kaiser (Georgia Department of Natural Resources). Litts and Kaiser developed a heads-up digitizing method (Table 2), and one objective was to compare this classification with one obtained by using image correction/automatic classification methods available with more costly image analysis packages.

Mr. Hook conducted a side-scan sonar scan of the Ogeechee River and evaluated the potential for suitable spawning locations based on his survey. Side scan and multi-beam sonar surveys were performed on the Ogeechee River from river kilometer (rkm) 32 near Fort McAllister to approximately rkm 320 near Louisville, Georgia from January 2009 to June 2009. The whole navigable (with small boat) Ogeechee River was run with side-scan and 3D SONAR from February - June 2009, with additional targeted stretches being scanned during April, 2010. Surveys were performed at high flows using Hummingbird® 
997SI side scan and 967C multi-beam sonar systems. Side-scan recordings were georeferenced (longitude, latitude) and the resultant imagery imported into ArcGIS. Side scan images were used to digitize the stream banks. A depth profile of the potentially suitable reaches during springtime flows was then created using Inverse-Distance Weighting to interpolate between the digitized banks and the multibeam swaths.

Stream substrate was visually interpreted. Hard substrates found included exposed limestone bedrock, small limestone boulders, coarse gravel, hard-consolidated clay, and landowner-placed rip rap. The remaining substrates identified consisted of sand, soft clay, and silt sediments. We assumed that all hard substrates - exposed bedrock, cobble, gravel, boulders, and hard consolidated sediments - were potentially suitable for use by sturgeon. All other substrate types were deemed unsuitable.

Multi-beam data were used to construct a bathymetric profile of stream reaches containing potentially suitable substrates. Depths at these locations during the survey periods ranged from 1.1 meters at the most downstream reach at river kilometer $(\mathrm{rkm}) 84.3$ to a maximum depth of 5.6 meters at one of the most upstream reaches at rkm 219.6. The Ogeechee River swelled by more than three meters over the following two weeks and all reaches identified as containing suitable substrates would have met minimum depth requirements at some time during the February through April time-frame for Atlantic sturgeon spawning movements in southern rivers. The minimum depth associated with a documented Atlantic sturgeon spawning location is $1.5 \mathrm{~m}$ (Collins et al. 2000a); therefore, this depth was deemed the minimum potentially suitable depth in this study. Shortnose sturgeon have similar requirements. Collins et al. $(2000 \mathrm{~b} ; 2002)$ used telemetry of juvenile shortnose sturgeon in nursery areas with depths between 2.1 and $13.4 \mathrm{~m}$.

Table 2. Classification scheme developed by Litts, Kaiser, and Wes Tracy to identify habitat from sidescan sonar data.

\begin{tabular}{|l|l|l|}
\hline Substrate type & Code & Description \\
\hline Sandy & $\mathrm{S}$ & An area predominantly $(>75 \%)$ composed of particles $<15 \mathrm{~mm}$ \\
\hline Rocky fine & $\mathrm{Rf}$ & $\begin{array}{l}\text { An area predominantly composed of rocks from } 16 \mathrm{~mm} \text { to } 500 \\
\text { mm in diameter across the widest side }\end{array}$ \\
\hline Rocky boulder & $\mathrm{Rb}$ & An area with $\geq 3$ boulders $(\geq 500 \mathrm{~mm}$ ) within 3 m of each other \\
\hline Limestone fine bedrock & Lb & An area predominated by solid limestone bedrock \\
\hline Limestone outcrop & Lo & $\begin{array}{l}\text { Any limestone outcropping that is deeply fractured or shaped into } \\
\text { blocks }>500 \text { mm, includes limestone walls }\end{array}$ \\
\hline Mixed & Mx & A heterogenous mixture of rocky types with sand or limerock \\
\hline No data & No & Beyond sonar range \\
\hline Sonar shadow & SS & Dark areas caused by objects blocking sonar beam \\
\hline Unsure sandy & Us & An area with sonar distortion that is likely $>75 \%$ sand \\
\hline Unsure rocky & Ur & An area with sonar distortion that is likely $>75 \%$ rocky \\
\hline Island & Isl & $\begin{array}{l}\text { Islands that may be occasionally inundated during high flow } \\
\text { events }\end{array}$ \\
\hline
\end{tabular}


UGA surveyed three 1-km sites on the Ogeechee River, Georgia, using Hummingbird side-scan and multi-beam sonar units. In addition, 3D (depth) data were collected for the whole river. The images were processed at three levels of effort and complexity, from raw images exported as bitmaps, to extensively manipulated images which were normalized, corrected for slant-range distortions and geo-referenced. Substrate type was classified using heads up and automated techniques and accuracy was assessed across all methods. Greatest accuracy was achieved using raw images, with lower accuracy at greater levels of processing. Heads up classification yielded greater accuracy than automated for all processing levels. Our results indicate a trade-off between processing complexity and accuracy. Ecologically relevant habitat variables can be derived even at the lowest levels of processing effort and complexity, but are limited to location by river kilometer and proportional area of a given substrate class. Fully processed images allow for importation into a GIS and determination of area and position, at the cost of effort and accuracy.

The timing of substrate characterization did not allow us to specifically represent spawning locations in the PVA. However, it is possible to compare our assumptions about upstream spawning distances with those simulated.

\section{FISHERY BY-CATCH}

We planned and implemented a survey of shad nets in the Ogeechee River in the first year. We also obtained state regulations that govern days during which shad fishing is legal. Next, we implemented capture and harvest as by-catch in the PVA model using information from our survey on net locations, legal fishing dates and published survival rates for captured shortnose sturgeon. PVA-simulated individual adults migrating upstream were subject to capture in shad nets only during these times. Finally, we ran simulations with and without by-catch mortality to assess the quantitative influence on simulated population persistence. 


\section{RESULTS AND DISCUSSION}

\section{SHORTNOSE STURGEON WORKSHOP}

A workshop report was submitted to SERDP in March, 2007. Workshop participants stressed the importance of spawning and early lifestages and the importance of water quality as a priori factors that might limit the Ogeechee shortnose sturgeon population. Those attendees that participate in the Ogeechee River Working Group and the northern shortnose sturgeon biologists believe that spawning habitat and early life stages are the most critical phases. However, spawning locations are not well described but likely occur adjacent to Fort Stewart, upstream of the Canoochee confluence. One concern is that age-0 sturgeon will drift downstream into brackish conditions near the tidally influenced area adjacent to Fort Stewart before developing saltwater tolerance. Spatially, the main implication for the modeling is that the model should represent the river habitat far enough upstream to capture reproduction.

Participants also emphasized the importance of water quality, including Fort Stewart's influence on biological oxygen demand and dissolved oxygen, and the role of saltwater intrusion as mediated by rice canals and groundwater extraction from the upper aquifer.

As a result of the workshop, we revised our plan in a number of ways. We shifted emphasis from sedimentation and its potential effects on early lifestages of shortnose sturgeon from the Canoochee River to the Ogeechee River farther upstream where spawning takes place. We increased emphasis on water quality in the saltwater-freshwater interface. Therefore, we modified the planned watershed study on Fort Stewart to focus on water quality impacts rather than sediment impacts. In addition, we added plans to evaluate the impacts of saltwater inputs through the rice canals.

Based on one workshop presentation, we eliminated groundwater withdrawal as a potential influence on shortnose sturgeon. Dr. Reichard's isotope tracer study did not demonstrate connection between the deep Floridian aquifer, the source of groundwater targeted by pumping, and surface water in the OgeecheeCanoochee Rivers. Finally, we added plans for a field survey of shad nets to ensure accurate simulation of by-catch mortality.

\section{PVA MODELING}

We developed an individual-based and spatially-explicit PVA model for shortnose sturgeon. An empirical method for linking salinities in the zone of rice canal influence with those farther downstream was implemented and used to assess effects on shortnose sturgeon. We addressed several research questions using the PVA model to evaluate whether the population limited by spawner numbers or habitat, in the absence of other influences?

a. What is the minimum viable population size?

b. What is the minimum amount of habitat required for persistence?

c. Do rice canals have a significant negative effect on juvenile habitat?

We addressed the first set of research questions by evaluating two extinction thresholds of interest: minimum viable population size (MVP) and minimum habitat.

Spawner limitation - To estimate MVP, we simulated the Ogeechee River population with two initial population sizes and river lengths (Figure 9). An operational definition for MVP using this approach is the initial size for which at least $95 \%$ of replicate populations persist. We note that this operational definition does not, strictly speaking, identify a threshold as larger initial populations take longer to reach extinction even if the same outcome will eventually be reached.

We compared simulations with and without immigration. Simulated "open" populations, i.e., those with immigration, experienced a higher likelihood of persistence compared with the simulated isolated populations (Figure 10). Emigration was allowed but never occurred in the simulations, possibly because this could only occur from the bottom-most cell. 


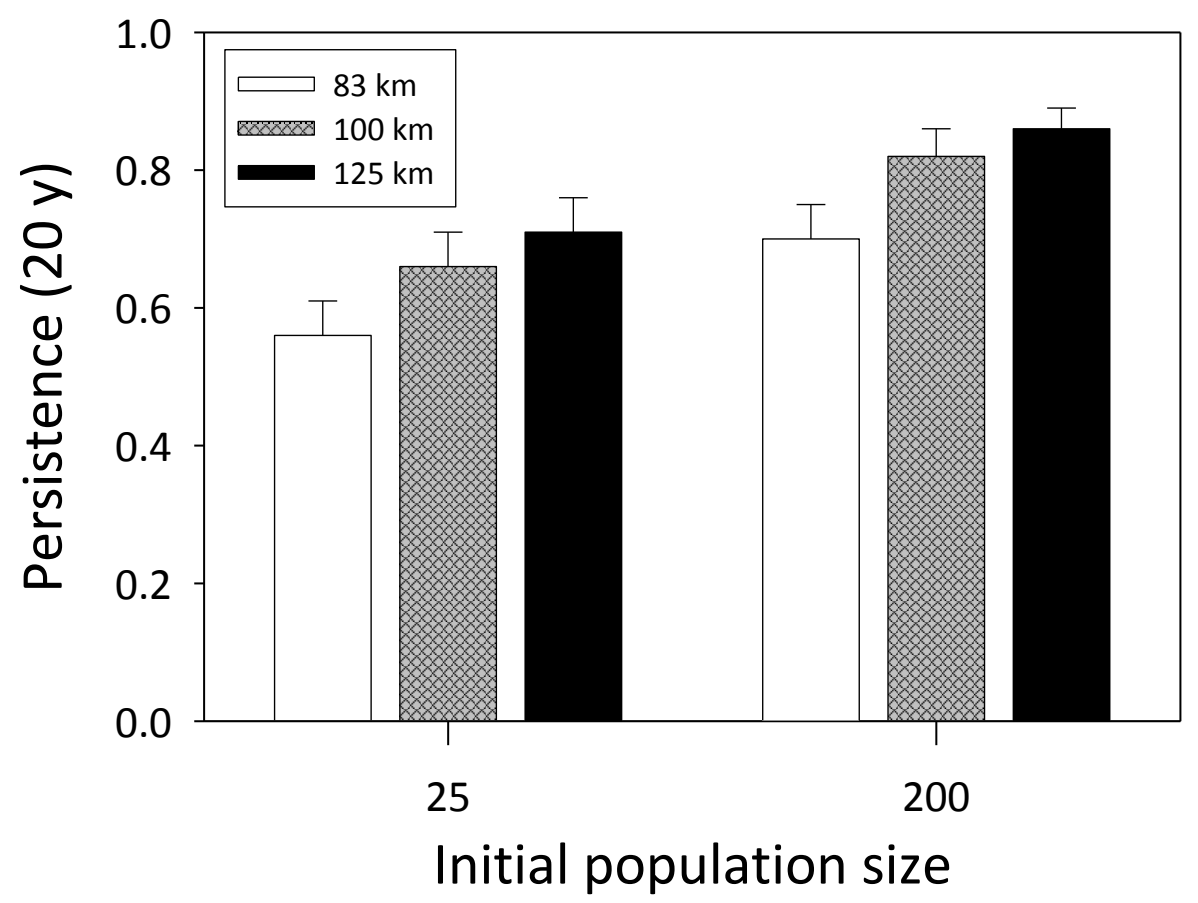

Figure 9. Ten-year time series for each of 30 replicate shortnose sturgeon populations starting with an initial population of 150 individuals and 1985-1995 historical climate and river flow. Results are shown for three river lengths, 83,100 , and $125 \mathrm{~km}$, corresponding to the simulated location of spawning.

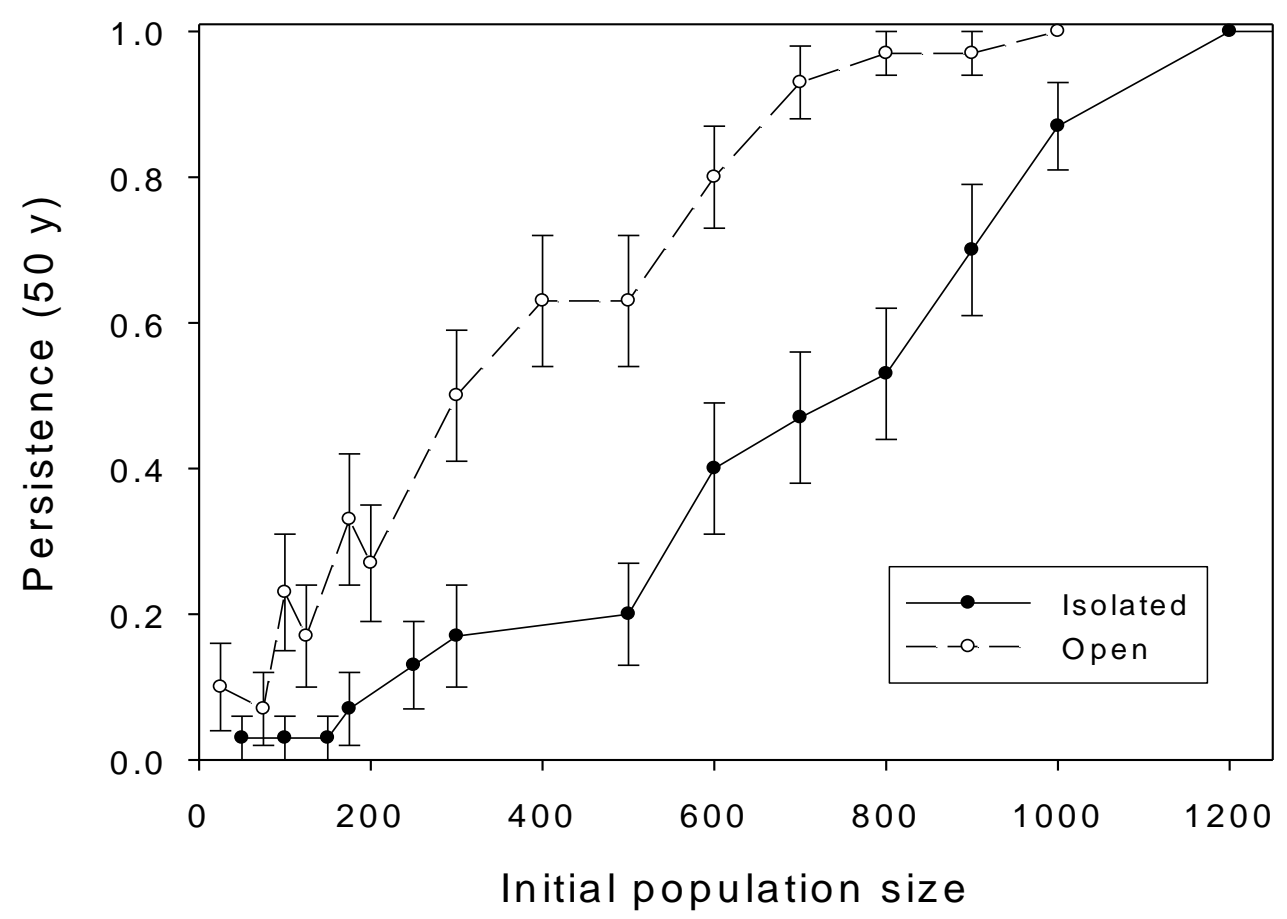

Figure 10. Model-predicted increase in population persistence over 50 y for different initial population sizes. We simulated immigration for the open population but not for the isolated population. 
Habitat limitation - We compared persistence over 20 historical years using three different assumptions about where spawning occurred, at 83,100, and $125 \mathrm{~km}$ upstream. The fraction of replicate populations that persisted increased with distance upstream (Figure 10) for a range of initial population sizes. We observe that the time horizon for these simulations is quite short $(20 \mathrm{y})$. This is because our model is designed to run historical years and is not yet adapted to forecast future climate conditions. We note that persistence over $20 \mathrm{y}$ is not a highly encouraging result when one is really interested in the long-term prognosis.

We investigated the relationship between river length and relevant sources of mortality represented in the model to understand our results. Our bioenergetics growth model, when embedded in the PVA model, predicted that a fraction of juveniles starved during their first summer. Pulses of reproduction in spring resulted in depletion of prey over summer, as illustrated by alternating sturgeon and prey peaks in Figure 11. Together, premature exposure to salinity and density-dependent starvation accounted for higher juvenile mortality in populations simulated to be restricted to a shorter section of the Ogeechee River. We discovered an interesting trade-off between upstream starvation and premature exposure to high salinity. Juveniles choosing to remain upstream experienced high rates of starvation, whereas those moving downstream were killed by elevated salinities.

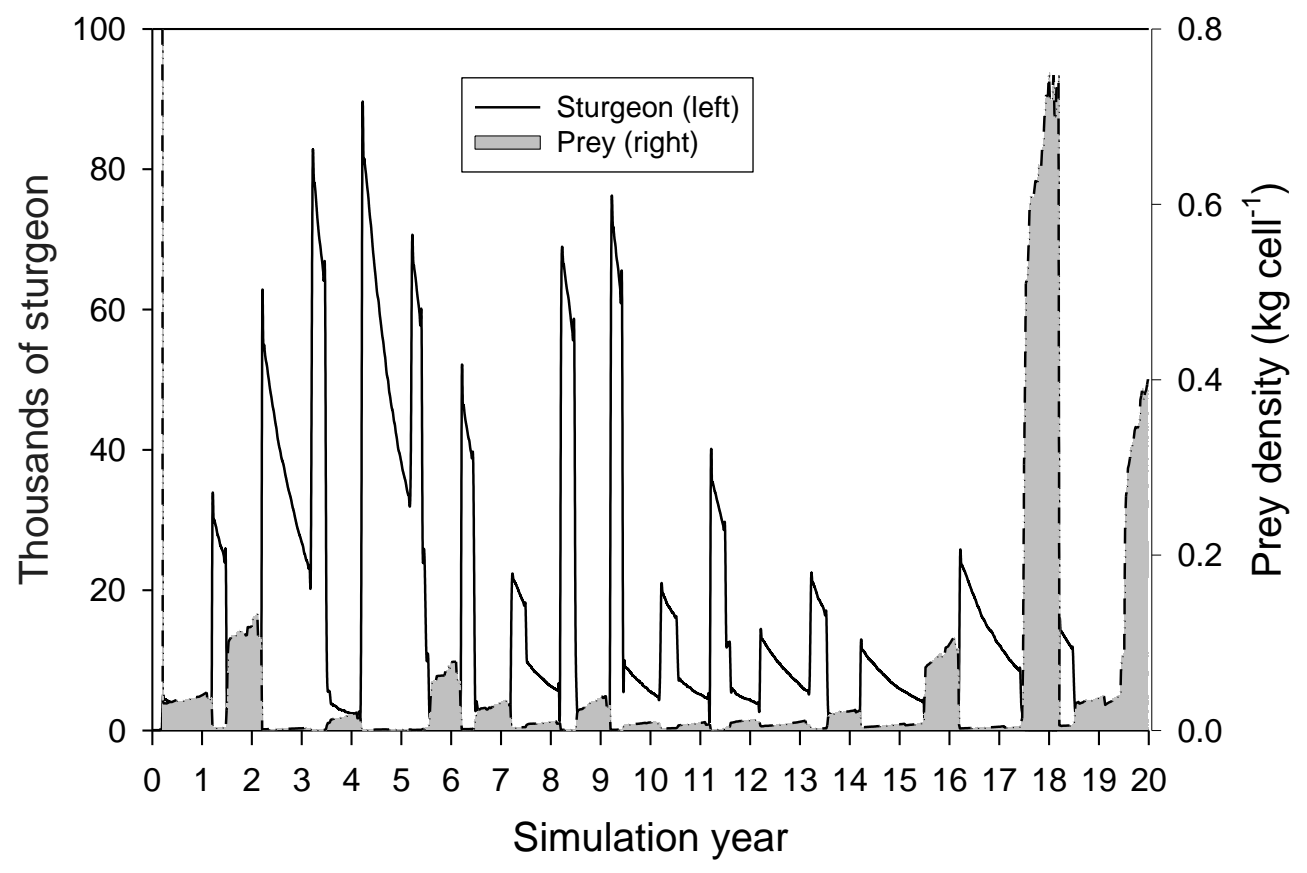

Figure 11. Model-simulated shortnose sturgeon population dynamics and prey dynamics over a twentyyear simulation.

One of the main objectives of this study was to compare anthropogenic threats to the population. To address the second set of questions, we evaluated the relative importance of three factors (by-catch harvest, poor water quality/habitat, rice canals) on population viability. According to the PVA model, all three were determined to have an influence, as summarized by Figure 12. Simulated habitat-related mortality had its largest numerical impact during the first year, acting on the juvenile life stage as described earlier. 


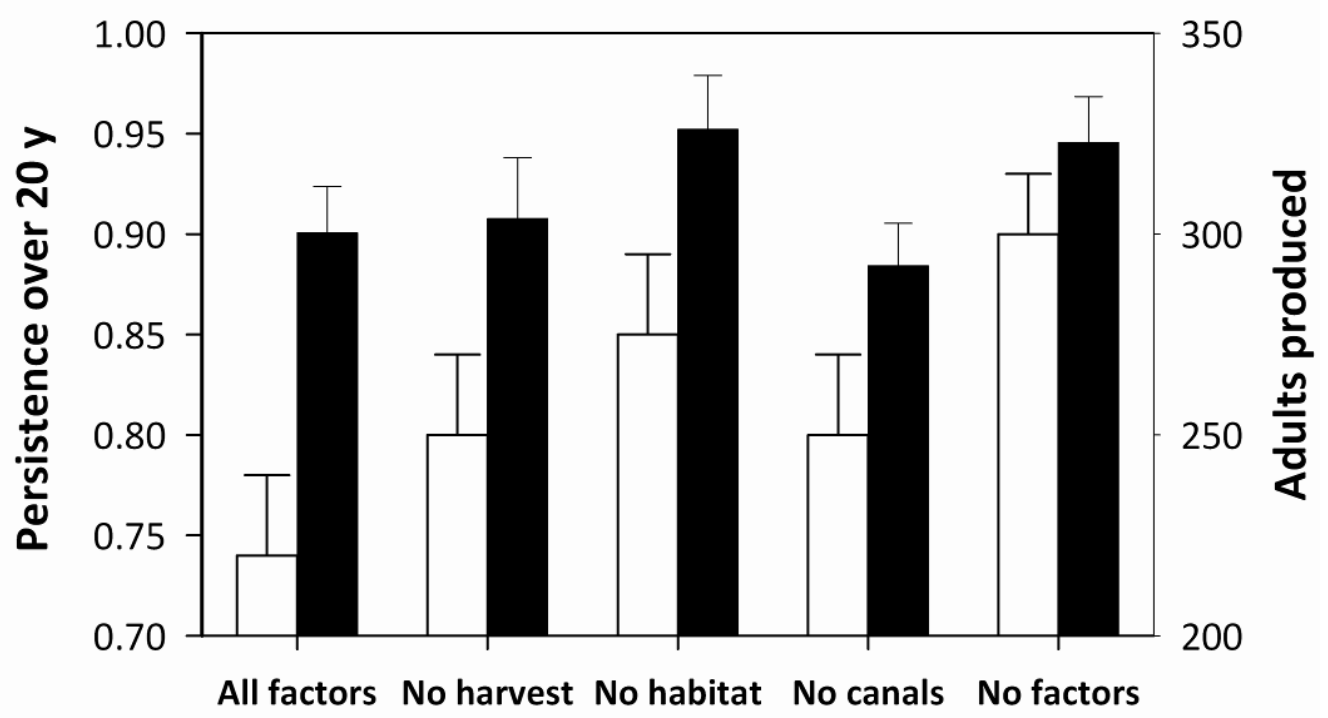

Figure 12. Fraction of 100 replicate populations (white) that persisted and the average number of adults produced (black) and over a twenty-year period for each of five scenarios in which factors were removed. Values presented are for an initial population size of 225 individuals. Error bars indicate \pm 1 SE among replicate scenarios.

The effects of the three factors were clearly not additive (Figure 12), but removing the effects of all three factors produced a larger benefit to persistence than any one factor alone. Of the three individual factors, habitat (water quality) appeared to have the largest effect. Cumulative mortality in simulations with one or more factors "turned off" illustrates the effects of these factors (Figure 13), some of which (i.e., harvest) will be described in later sections.

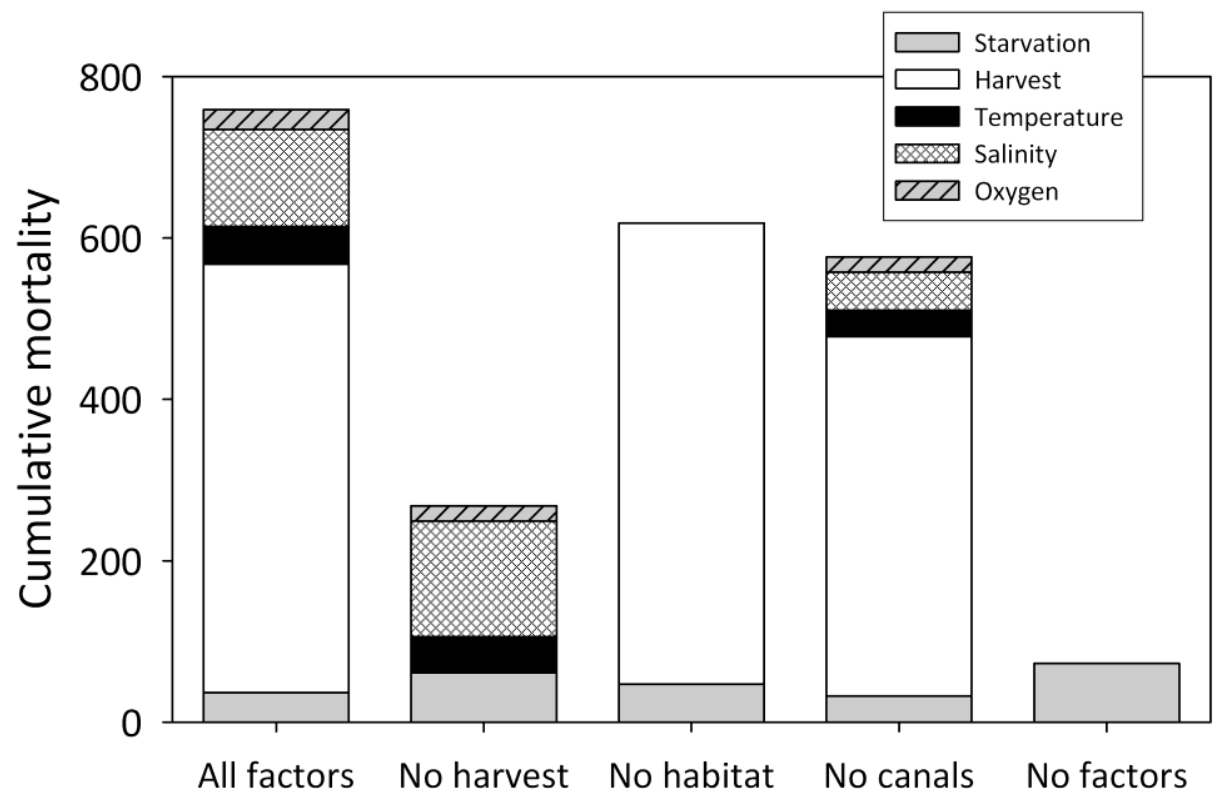

Figure 13. Average simulated mortality with all sources of mortality, without harvest, without rice canals, and without any sources of habitat mortality, and without any of the three factors. Values are averaged over 100 replicate simulations for an initial population size of 225 individuals. 


\section{MERCURY TOXICITY}

The first three tasks leading toward assessment of mercury effects on shortnose sturgeon were to model bioenergetics, to add uptake of mercury along with biomass, and estimation of prey concentrations of methyl mercury. We completed all three of these tasks. The bioenergetics model developed for shortnose sturgeon provided the underpinning for modeling mercury uptake.

Mercury uptake was incorporated into the bioenergetics model as described in the Methods section. We simulated whole body and egg concentrations bracketing the range measured in amphipod prey, 0.04 to $0.1 \mathrm{mg} / \mathrm{kg}$ (Figure 14). We found that model-predicted concentrations in gonadal tissue were lower than those measured (open bars in Figure 15). Samples taken during 2008 were analyzed for methyl and total mercury. These values were incorporated as input to the mercury accumulation model and used to predict concentrations in somatic and gonadal tissue for a female shortnose sturgeon.

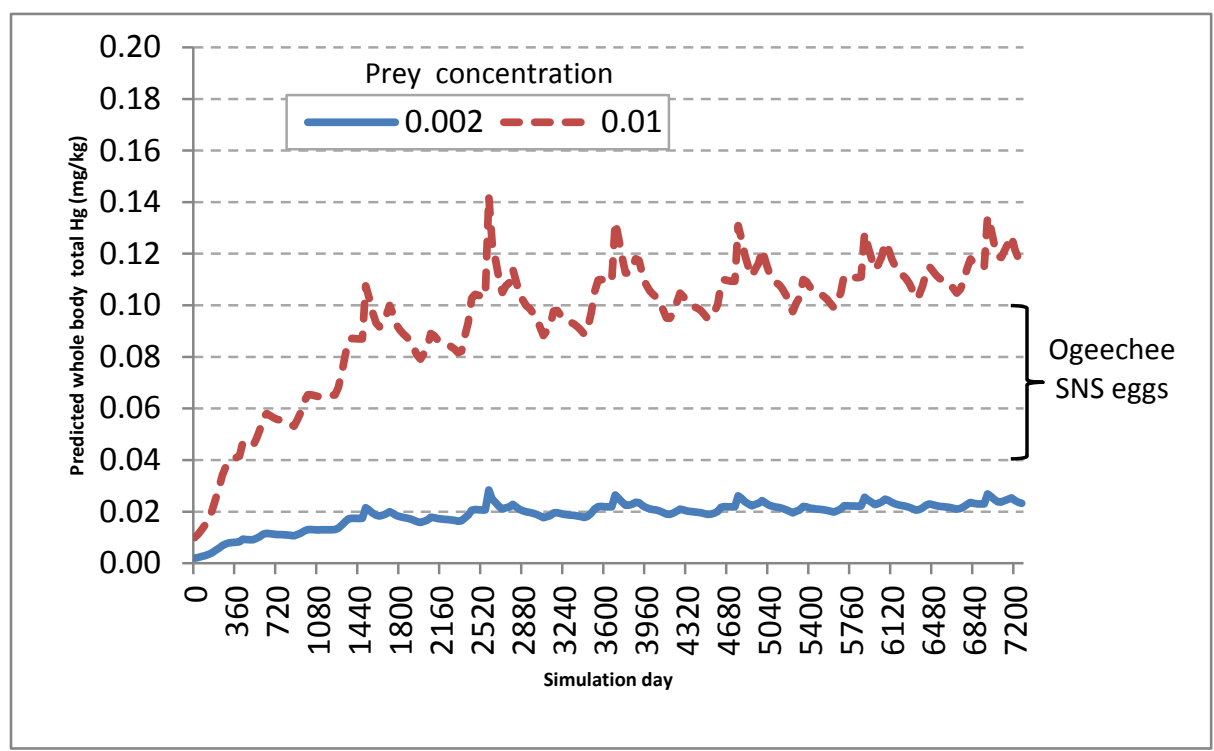

Figure 14. Simulated whole body total $\mathrm{Hg}$ in shortnose sturgeon for two prey concentrations that bracket values measured in Ogeechee River amphipods.

The simulated wholebody total mercury concentration was below the USEPA threshold of $1.0 \mathrm{mg} / \mathrm{kg}$. If we adopt higher prey concentrations of mercury that are consistent with measured egg concentrations, we get estimates between 0.27 and $0.66 \mathrm{mg} / \mathrm{kg}$, which is closer to, but still below the regulatory threshold. There is no information on the toxicity of methylmercury to early life history stages of shortnose sturgeon to indicate whether these levels are likely to have effects on normal development.

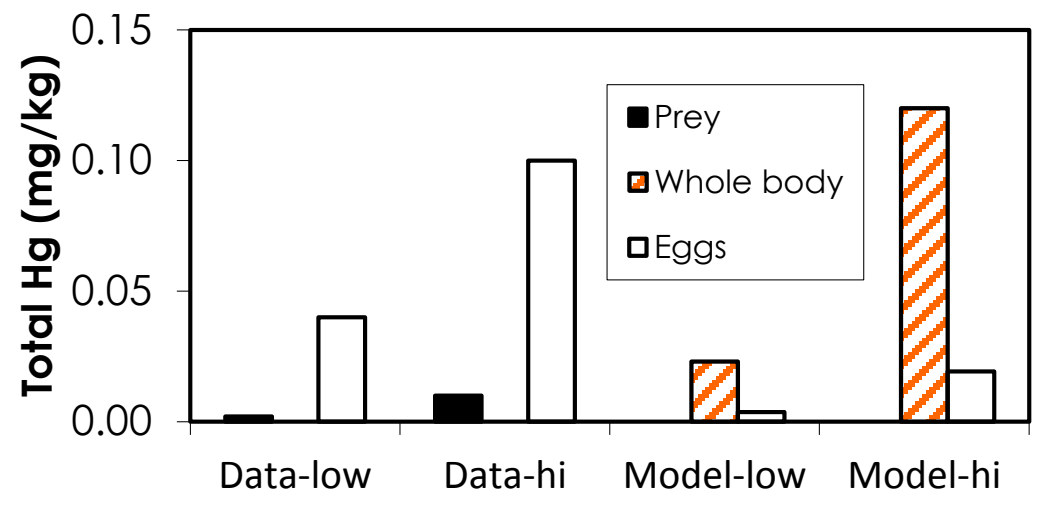

Figure 15. Comparison of measured data and modelpredicted whole-body concentrations in amphipod prey (solid bars), shortnose sturgeon (striped bars), and shortnose sturgeon eggs (open bars) for two levels bracketing measured prey concentrations. 


\section{WATER QUALITY}

Three objectives of this task were to characterize water quality in the Ogeechee and Canoochee Rivers and to develop equations to estimate water quality parameters in the lower Ogeechee River for use in the PVA model.

Ogeechee Sampling. - In the Ogeechee River, the lowest values of DO occurred in summer. Nearly $40 \%$ of biweekly DO measurements measured during the months from June to September were below $4 \mathrm{mg} \mathrm{L}^{-1}$ (Figure 16). Variability in summer DO was high and only partially explained by variation in temperature and flow. Spatially, there was not much evidence for a DO sag below the Canoochee inflow at river km 56 , but DO values below $4 \mathrm{mg} \mathrm{L}^{-1}$ were not uncommon in the transition zone. Concentrations below 3.5 $\mathrm{mg} \mathrm{L}^{-1}$ have been associated with increased routine metabolism, decreased growth, and mortality in juvenile shortnose sturgeon (Niklitschek and Secor 2009). The lowest DO (2.24 mg L $\mathrm{L}^{-1}$ ) was recorded during the pre-dawn period in June, which could have been caused by night-time algal respiration. Surface and bottom values were not significantly different.

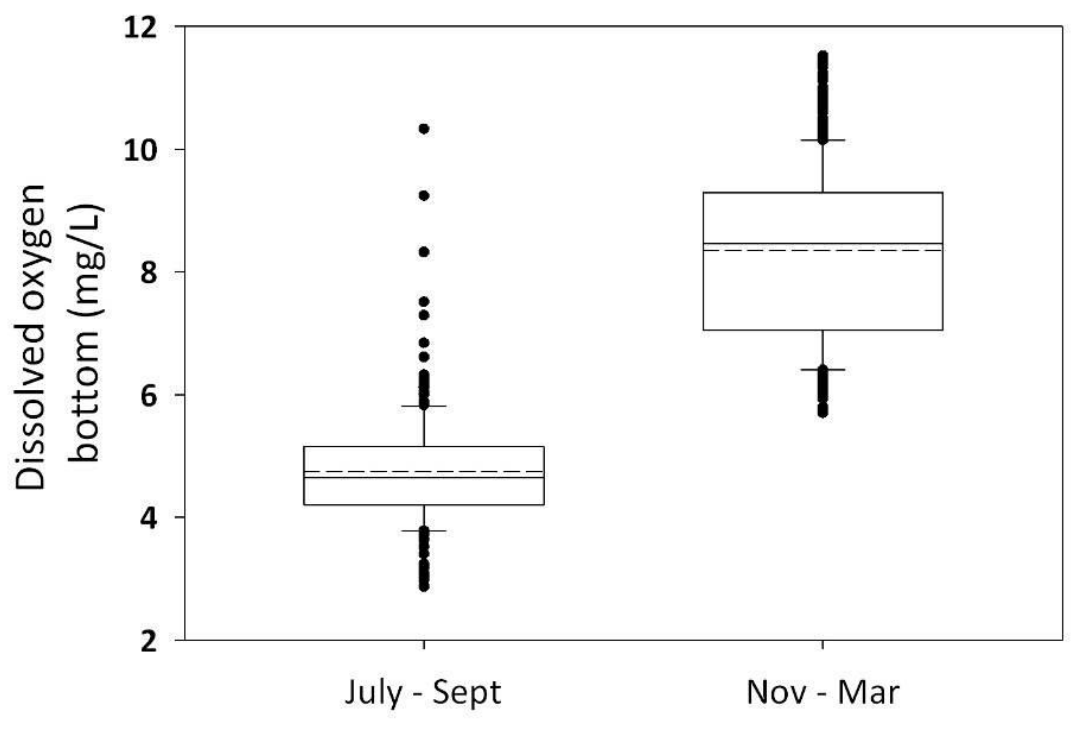

Figure 16. Distributions of biweekly dissolved oxygen measurements in summer months (June to Sept) and winter months (Nov - Mar), 2007 to 2009 in the lower Ogeechee River. Each box extends from the lower $25^{\text {th }}$ to the $75^{\text {th }}$ percentile, with the median and mean shown as solid and dashed horizontal lines, respectively. Upper and lower whiskers indicate $5^{\text {th }}$ and $95^{\text {th }}$ percentiles, and symbols show extreme values.

Canoochee Sampling.-The general pattern observed for most analytes (Figure 17) was that of lower concentrations in the NW branch of the Canoochee River, and higher concentrations in the SW branch (Canoochee Creek). Like headwater samples, nitrogen was dominated by organic forms (Figure 17A). Levels of organic nitrogen were much higher in the storm samples collected in 2008 than in the base-flow samples collected in 2009. Inorganic nitrogen in the 2008 tropical storm Faye samples and in 2009 samples upstream of Bridge 38 was primarily in the form of $\mathrm{NH}_{4}{ }^{+}$(Figure 17A). In contrast, levels of $\mathrm{NO}_{3}$ were much higher than $\mathrm{NH}_{4}{ }^{+}$in two bridge samples taken downstream of a large training area north of the Canoochee River and Canoochee Creek 


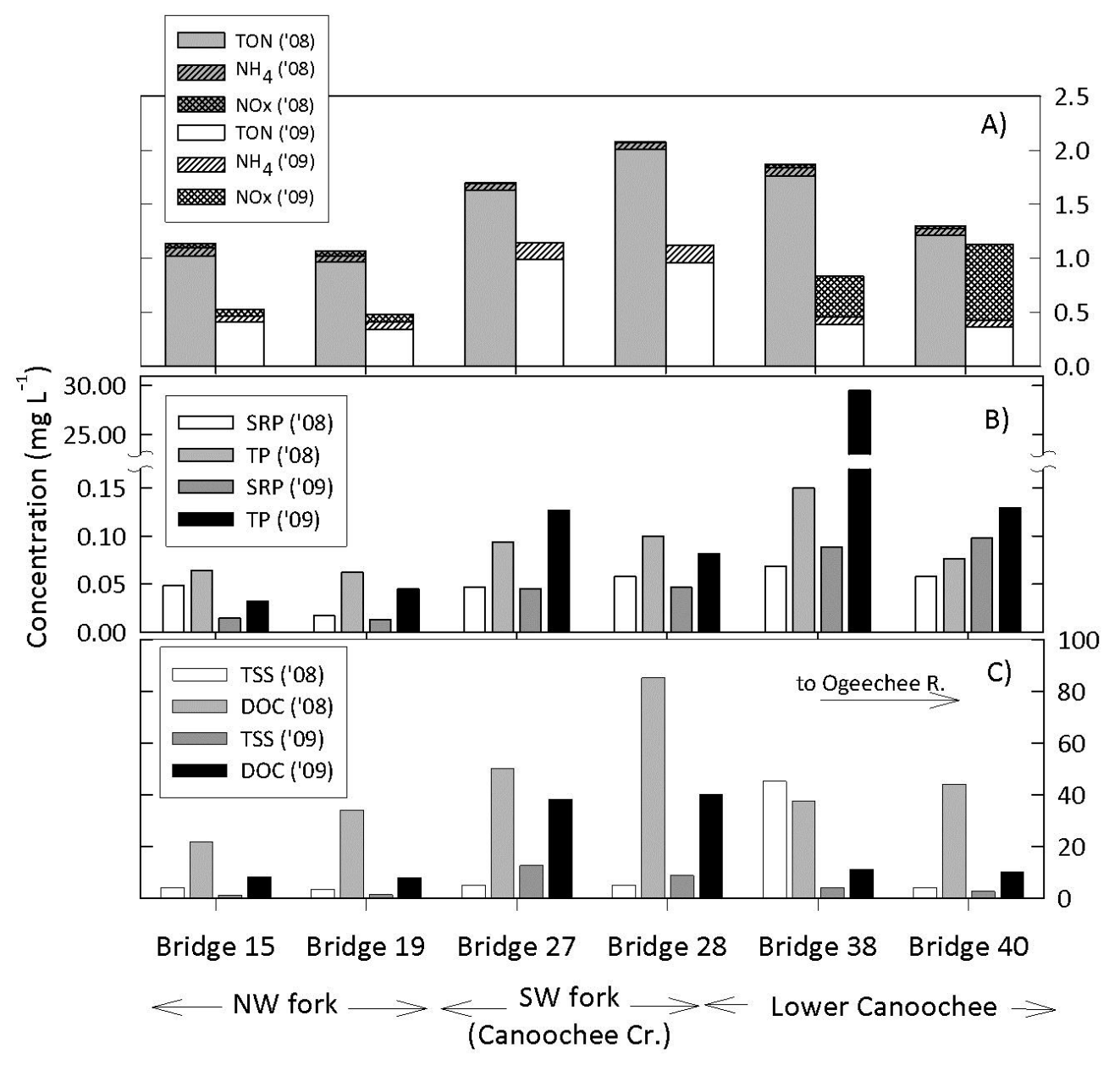

Figure 17. Water chemistry measurements, including A) nitrogen, B) phosphorus, C) total suspended solids (TSS), and dissolved organic carbon (DOC), taken from six bridges on the lower Canoochee River on two occasions (August 2008 and August 2009). Bridges 15 and 19 are on the upper branch of the Canoochee River. Bridges 27 and 28 are located below Taylor Creek on Canoochee Creek. Bridges 38 and 40 are located on the Canoochee River downstream of the Canoochee Creek confluence and downstream of a large, barren area used for training.

Phosphorus levels were lowest in the upstream Canoochee River samples (Bridges 15 and 19, Figure 7) and high in the Canoochee Creek (Bridges 27 and 28) and lower Canoochee River samples (Bridges 38 and 40) (Figure 17B). In 2008, the highest TP value (at Bridge 38 in Figure 17B) coincided with the highest TSS value. TP measured (and re-measured to confirm) at Bridge 38 in the 2009 sample was extremely high $\left(29 \mathrm{mg} \mathrm{L}^{-1}\right)$, but values at downstream Bridge 40 were considerably lower (Figure 17B). However, TSS at Bridge 38 was not particularly high in the 2009 samples (Figure 17C).

A large peak in TSS was measured during storm Faye in 2008 at Bridge 38 (Figure 17C). This particular bridge is below a large barren, training area with several artillery ranges in the center of Fort Stewart. This peak did not correspond with high values in samples from either of the upstream branches, and also seemed to be ameliorated by the time water reached Bridge 40. DOC was higher in the Canoochee Creek samples (Bridges 27 and 28) than in the upstream Canoochee River samples (Bridges 15 and 19), with intermediate values downstream after their convergence (Bridges 38 and 40), as shown in Figure 17C.

DOC showed a similar spatial pattern to that of ON, with low values in the upper Canoochee and high values in Canoochee Creek (Bridges 27 and 28 in Figure 17C), with intermediate values farther 
downstream beyond the Canoochee Creek confluence. Concentrations of DOC in the 2008 storm Faye samples at Bridges 38 and 40 were 3 or 4 times higher than those during 2009 base-flow conditions (Figure 17C). To assess the potential of DOC to flocculate and thus increase its availability to heterotrophic microbes in the benthos, we measured POC formation after adding seawater to DOC samples collected at Bridge 40 on three occasions. In our August 2008, March 2009, and May 2009 samples, $17.1 \%, 17.9 \%$, and $23.7 \%$ of DOC flocculated as POC, respectively. We concluded that approximately $20 \%$ of DOC would become POC upon reaching the freshwater-saltwater interface in the Ogeechee River.

Ogeechee Modeling.-The PVA model requires three water quality variables, temperature, salinity, and dissolved oxygen. High temperatures and salinities and low levels of dissolved oxygen are assumed to cause mortality after one day of exposure. According to Secor and Niklitschek (2001), age-0 shortnose begin to exhibit physiological and behavioral changes to DO below $4.5 \mathrm{mg} / \mathrm{L}$ when temperatures are in the range $22-27^{\circ} \mathrm{C}$. Tolerances of older fish have not been characterized. Habitat quality is reduced for water quality in poor and marginal ranges, which influences habitat choice.

We defined relationships for each of the three variables as functions of one or more of the following variables: distance from the ocean, $X$ in river km, flow below the Black Creek and Ogeechee River confluence, season and the other two water quality variables. These relationships are described below. We also added normally distributed error, $\varepsilon$, with zero mean and standard deviation $1.96 *$ sqrt (mean square error) to each fitted relationship used to predict water quality, Equations 6 to 9. This is considered a reasonable approximation of the prediction error when sample sizes are large.

Equation 6 describes a relationship fitted to salinity data collected in the Ogeechee River below the influence of rice canals and reported in graphs by Sheldon and Alber (2005). This relationship, with parameters estimated using SAS ${ }^{\mathrm{TM}}$ NLIN, explained $75 \%$ of variation in salinity.

$$
S(x, Q)=S s w\left(1-\frac{x}{x+\mathrm{e}^{\left(\frac{\text { Salina }+ \text { Salinc } Q}{\text { Salin }+ \text { Salind } Q}\right)}}\right)+\varepsilon_{2} .
$$

To simulate salinity influences of rice canals, salinities between river km Rice_low and Rice_hi were set to those at a downstream location, Rice_ptr. This downstream location was selected by visually comparing movies of salinities simulated using the Environmental Fluid Dynamics Code (EFDC) with and without rice canals. The EFDC model was calibrated to simulate temperature and salinity in the Ogeechee River.

Seasonal variation in water temperature was modeled from air temperature, $T_{\text {air }}$ and Julian day based on data at the Eden gage on the Ogeechee River (Equation 7). We simulated air temperature using Equation 7, which we fitted to over fifty years of National Climate Data Center data measured at the Savannah International Airport.

$$
\begin{gathered}
T_{w}(\text { day })=w_{0}+w_{t} T_{a i r}(\text { day })+\varepsilon_{1} \\
T_{a i r}(\text { day })=T_{a v g}+\left(T_{\text {max }}-T_{a v g}\right) \sin \left(\frac{2 \pi}{365}\left[d a y-J_{0}\right]\right)
\end{gathered}
$$

We predicted water temperature from air temperature and Julian day. Note that the equations above can be used to simulate future water temperatures.

We used our water quality survey data for the Ogeechee River to evaluate seasonal and longitudinal variation. Because bottom and surface measurements were not significantly different, we used an average 
if both were available and either available measurement if not. Longitudinal variation in temperature was not significant, but seasonal variation was significant (represented by the sine term in Equation 8). In the Ogeechee River, water temperature also showed a significant decrease in response to increased total flow (all three upstream gages). Season alone explained at least $94 \%$ of variation in water temperatures measured during 2007 - 2009. Lower oxygen levels occurred at high temperatures during summer and fall. Values below $4 \mathrm{mg} \mathrm{L}^{-1}$ were observed between July and September in the lower Canoochee River and below the Canoochee confluence on the Ogeechee River (Figure 16). Similar patterns were observed in the upper estuary between Fort McAllister and Ossabaw Sound (Dom Guadanoli, Georgia Department of Natural Resources, personal communication).

We fitted multiple linear regression models for dissolved oxygen. In the Ogeechee River, salinity, logtransformed total flow (all three gauges), water temperature, $T_{w}$, river $\mathrm{km}, X$, and the percent of upstream flow from the Canoochee River, \%Qc explained 79\% of variation in DO in the Ogeechee River (Equation 9). We subtracted $0.3 \mathrm{mg} \mathrm{L}^{-1}$ from the intercept to account for the fact that measurements are during the day, based on an average difference of $0.6 \mathrm{mg} \mathrm{L}^{-1}$ between day and night (Mulholland et al. 2005).

$$
D O=v_{0, O g}+v_{S, O g} S+v_{Q t} Q_{t o t}+v_{T, O g} T_{w}+v_{x} X+v_{p} p Q+\varepsilon_{3}
$$

\section{WATERSHED ASSESSMENT}

Research to understand water quality influences of military landscapes usually involves intensive sampling in a few watersheds. In this study, we developed a survey design of accessible headwater watersheds intended to improve our ability to distinguish land-water relationships in general, and training influences in particular, on Fort Stewart, Georgia. We sampled and analyzed water from watershed outlets (Jager et al. 2011).

We examined the distributions of water chemistry analytes measured in headwater watersheds. TSS measurements were highly variable (average 51.7 ; range 0.7 to $941.1 \mathrm{mg} \mathrm{L}^{-1}$; Figure 18A). The median DOC in our samples was $31.08 \mathrm{mg} \mathrm{L}^{-1}$, with a range from 2.76 to $63.94 \mathrm{mg} \mathrm{L}^{-1}$ (Figure 18A). Total nitrogen was dominated by organic forms of nitrogen $(85 \%)$ in these streams (Figure 18B). Inorganic nitrogen was primarily in the form of ammonium ions, $\mathrm{NH}_{4}{ }^{+}$(Figure 18B). On average, SRP represented approximately one-third of total phosphorus (Figure 18B). Median values of both TSS and TP were high after tropical storm Faye in August, 2008, but not after rainfall on and before March 30, 2009. 

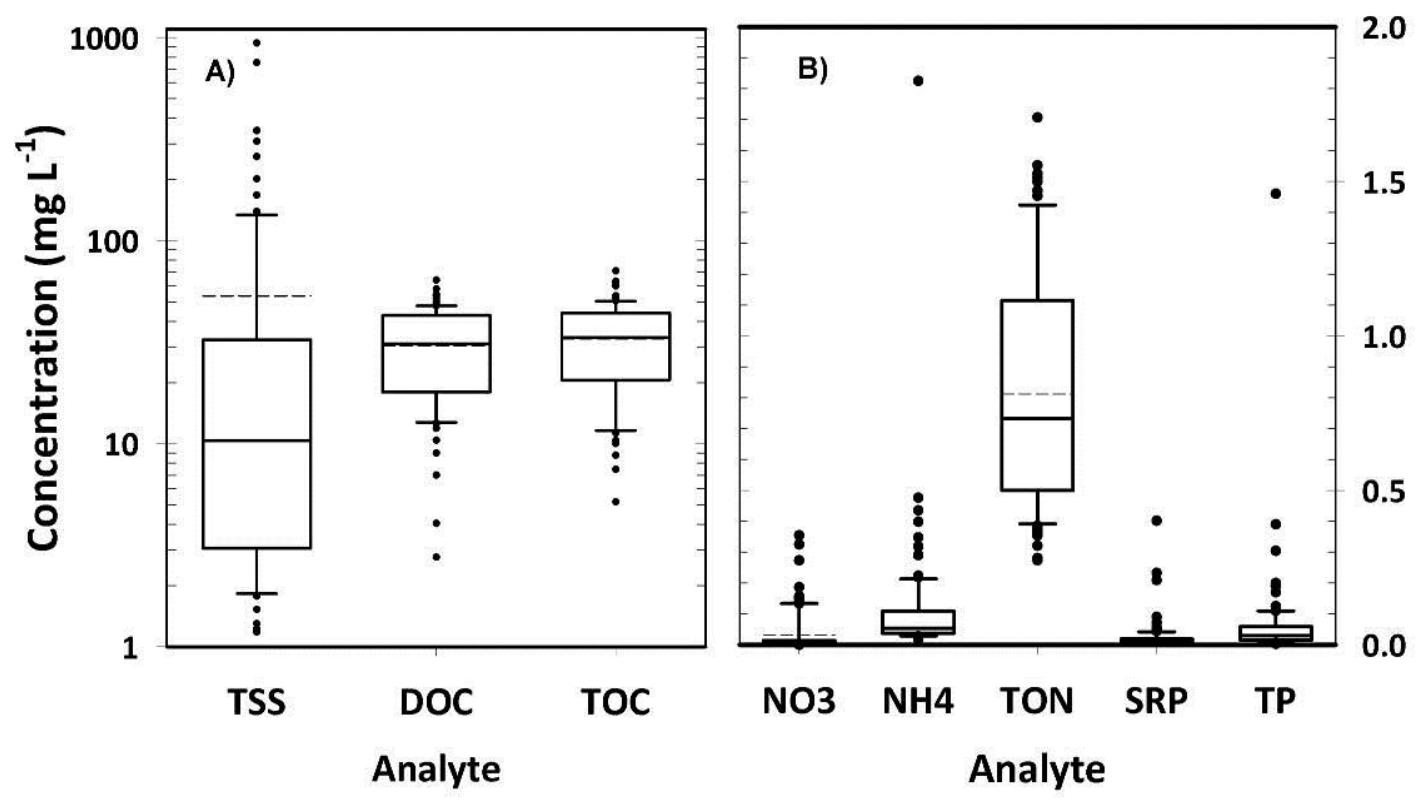

Figure 18. Water chemistry measurements from headwater watersheds on Fort Stewart, Georgia. Each box extends from the lower $25^{\text {th }}$ to the $75^{\text {th }}$ percentile, with the median and mean shown as solid and dashed horizontal lines, respectively. Upper and lower whiskers indicate $5^{\text {th }}$ and $95^{\text {th }}$ percentiles, and symbols show extreme values. Two groups are shown: A) Concentrations of total suspended sediment (TSS), dissolved (DOC), and total organic carbon (TOC) are reported in $\mathrm{mg} \mathrm{L}^{-1}$; B) Concentrations of $\mathrm{NH}_{4}{ }^{+}$, nitrate plus nitrite $\left(\mathrm{NO}_{3}\right)$, and organic nitrogen $(\mathrm{ON})$ are in $\mathrm{mg} \mathrm{N} \mathrm{L}^{-1}$. Concentrations of soluble reactive phosphorus, $\mathrm{SRP}$, and total phosphorus (TP) are in $\mathrm{mg} \mathrm{P} \mathrm{L}^{-1}$.

The highest positive correlations between pairs of measured water-chemistry variables were between DOC and TOC (0.960), TN and DON (0.895), TN and $\mathrm{NH}_{4}{ }^{+}(0.668)$, TN and SRP (0.707), TP and SRP (0.772), TOC and DON (0.598), TSS and $\mathrm{NO}_{3}(0.553)$. The highest negative correlation was between DOC and $\mathrm{NO}_{3}(-0.499)$ and DOC and TSS (-0.424). Among watershed attributes, stream-crossing training activity was correlated with grassland area (0.611) and wetland area (0.459). Other positive correlations were found between road and bare ground (0.51), wetland and forest area (0.488). Negative correlations were found between months-since-burn and wetland (-456), and between months-since-burn and stream-crossing activity (-0.499).

We successfully developed correlative models for total suspended solids (TSS), total nitrogen, and organic $\mathrm{C}$ and $\mathrm{N}$, which dominated in this blackwater ecosystem. TSS tended to be higher in samples after rainfall and during the growing season and models that included \%wetland suggested a "build-andflush" relationship. We also detected a positive association between TSS and tank-training, which suggests a need to intercept sediment-laden runoff from training areas. Models for organic $\mathrm{C}$ revealed a negative association with \%grassland. Total and organic $\mathrm{N}$ both showed negative associations with $\%$ grassland, \%wetland, and \%forest. Unexpected positive associations were observed between organic C and equipment-training activity and between organic $\mathrm{N}$ and \% bare ground and roads. 


\section{SEDIMENTATION}

A side-scan sonar survey of the entire navigable portion of the Ogeechee River was completed by Nate Nibbelink and John Hook (UGA) using Humminbird SONAR units at a relatively fast speed. The survey found that substrate diversity was low, dominated by silt/sand substrate and relatively few sites with gravel/cobble substrates. Eight stream reaches totaling 50,892 square meters were identified as potentially suitable for spawning use by Atlantic sturgeon (Table 3, Figure 19). This represents $0.2 \%$ of the roughly $23,900,000 \mathrm{~m}^{2}$ surveyed. Of the $50,892 \mathrm{~m}^{2}$ identified, $34,949 \mathrm{~m}^{2}$ or $68 \%$ were naturally occurring hard substrates. The remaining $15,943 \mathrm{~m}^{2}$ consisted of introduced gravel and rip rap.

Table 3. Location, size, depth, and composition of potentially suitable spawning grounds for Atlantic sturgeon $(>1.5 \mathrm{~m})$ and shortnose sturgeon $(>2.2 \mathrm{~m})$ in the Ogeechee River, Georgia. Source: Hook (2011)

\begin{tabular}{|l|l|l|l|}
\hline $\begin{array}{l}\text { River } \\
\text { Kilometer }\end{array}$ & $\begin{array}{l}\text { Size } \\
\text { (sq. m) }\end{array}$ & $\begin{array}{l}\text { Depth } \\
\text { range }(\mathrm{m})\end{array}$ & Composition \\
\hline 84.3 & 6774.3 & $1.1-2.4$ & Consolidated clay, "mudrock" \\
\hline 134.8 & 2076.6 & $1.3-3.1$ & Exposed limestone bedrock \\
\hline 138.9 & 4934.1 & $1.4-3.8$ & 60 cm or smaller limestone boulders mixed with sand \\
\hline 139.5 & 5816.1 & $2.1-3.9$ & Exposed limestone bedrock \\
\hline 141.3 & 10711.2 & $2.3-4.6$ & Matrix of sand, exposed bedrock, and small boulders \\
\hline 180.4 & 4636.7 & $2.3-4.6$ & Exposed limestone bedrock and coarse gravel \\
\hline 219.0 & 4365.3 & $2.4-5.6$ & Concrete chunks, rip rap \\
\hline 219.6 & 11578.2 & $2.5-4.8$ & Concrete chunks, rip rap \\
\hline
\end{tabular}

The bad news is that we identified very few sites with suitable rearing substrate in the Ogeechee River. The good news from this study is that future studies can focus efforts to sample for eggs and larvae near these areas using egg mats to evaluate spawning success without too much difficulty. This assumes that spawning sturgeon actually focus their spawning activities at sites with these characteristics.

Our PVA modeling compared results for spawning distances of $83 \mathrm{~km}, 100 \mathrm{~km}$, and $125 \mathrm{~km}$. We note that the first suitable site moving upstream occurs near the confluence of the Black River and Ogeechee River, near $83 \mathrm{~km}$. Interestingly, tributary confluences are known to be used for spawning by sturgeon species including shortnose sturgeon (Collins et al. 2000b) and white sturgeon (A. transmontanus) (Perrin et al. 2003). Coarse substrates inputs can characterize these depositional areas. 


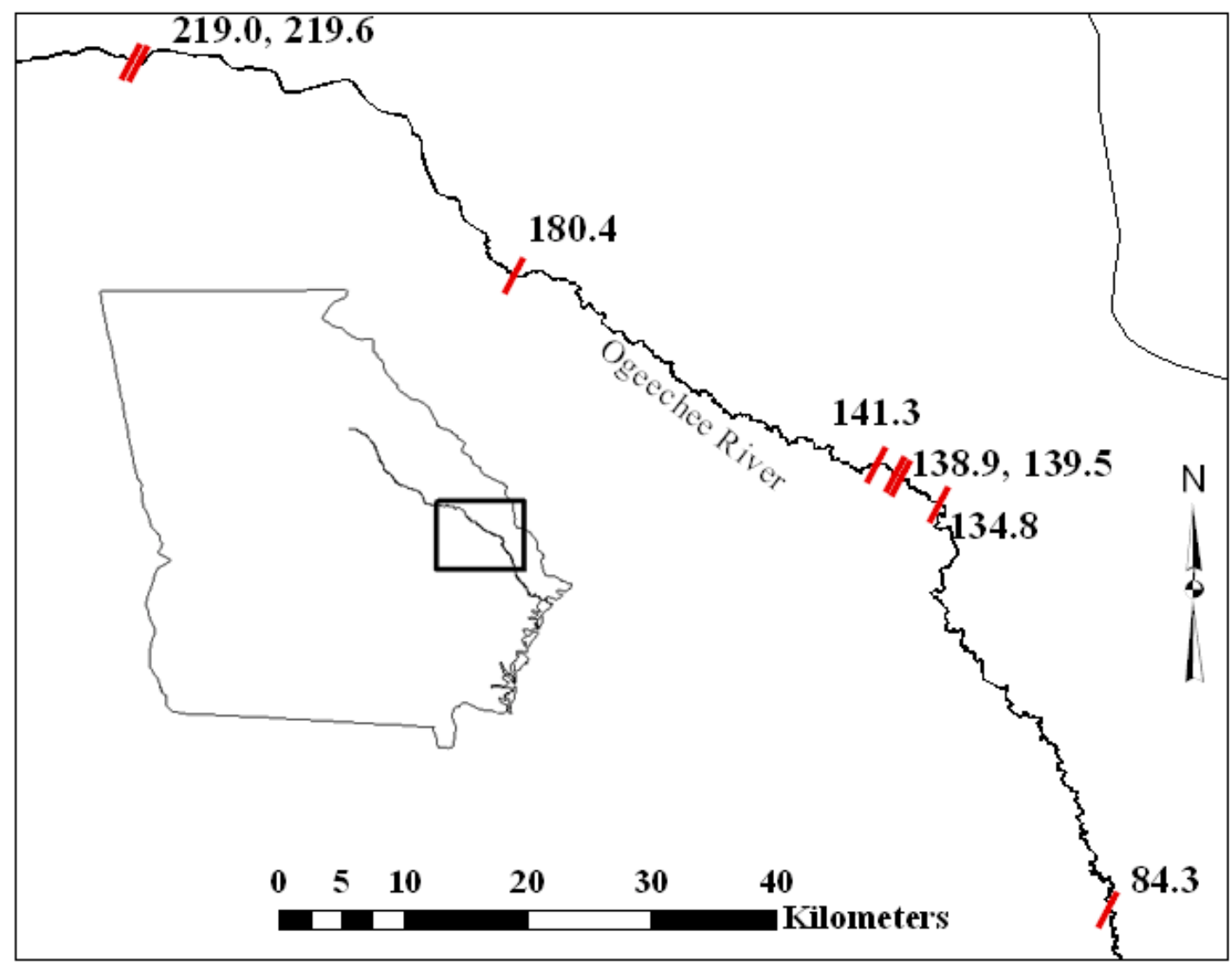

Figure 19. Potentially suitable spawning locations for Atlantic and shortnose sturgeon in the Ogeechee River, Georgia (river km). Results indicate low substrate diversity dominated by silt/sand substrate.

The UGA sonar survey did not address the role of military activities. However, we note that the first suitable substrate occurs at river km 84.3, and the Canoochee River, which drains most of Fort Stewart, enters the Ogeechee River at river km 55. Although we ruled out the potential impact of military activity on shortnose sturgeon in the Ogeechee River based on the physical downstream location of the Canoochee River, we note that other coastal installations with rivers that support sturgeon may experience effects caused by training activities that lead to sedimentation.

\section{FISHERY BY-CATCH}

We completed a by-catch survey in 2008. These data were used to estimate parameters for the harvest model. Simulations were conducted to evaluate the relative importance of by-catch to population viability. Although the effects of poor water quality on shortnose sturgeon habitat were predicted to have a larger individual impact than harvest, removing simulated harvest resulted in the largest reduction in mortality (Figure 13). 


\section{CONCLUSIONS AND IMPLICATIONS FOR FUTURE RESEARCH}

This project set out to address a number of scientific questions listed below about factors, military and non-military, influencing the shortnose sturgeon population in the Ogeechee River, adjacent to Fort Stewart in Georgia. Most of these were addressed during the course of the project. Other questions have been addressed by preliminary simulations but require additional simulations to obtain a complete answer. In addition, new questions were raised during the course of our study.

1. Is the population limited by habitat or spawner numbers?

a. What is the minimum viable population size?

b. What is the minimum amount of habitat required for persistence?

c. Do rice canals have a significant negative effect on juvenile habitat?

2. Is summer habitat limiting the Ogeechee River population?

3. Is the availability of coarse substrate limiting spawning in the Ogeechee River?

4. Is mercury limiting the Ogeechee River population?

5. Is harvest mortality as by-catch limiting the Ogeechee River population?

Our PVA study evaluated a wide range of potential threats to the shortnose sturgeon population in the Ogeechee River (Figure 3). Our results elevated the importance of habitat limitation for early life stages. Successful reproduction is likely affected by access to upstream spawning and incubation habitat with coarse substrates and deep water and by summer water quality in downstream habitat (dissolved oxygen and salinity). Harvest as by-catch in the shad fishery was also a non-negligible influence on simulated populations. By addressing the questions above, this study provide insights needed to design future research for and implement proper management of the Ogeechee River stock of shortnose sturgeon as well as other populations in the southern USA. These are discussed in the section below titled "Implications for Future Research".

Beyond this, we determined that connections with populations in the surrounding rivers are nonnegligible and that southeastern populations should be understood in terms of their metapopulation dynamics. The Ogeechee stock appears to be limited by persistent recruitment failure (Peterson and Farrae 2011). This study has generated interesting hypotheses about seasonal patterns of migration for this population that could be further explored using our spatially PVA model. Understanding the role of this river in the larger context of a metapopulation that includes populations in surrounding rivers is needed to help define distinct population segments (DPS's) and to develop meaningful recovery goals.

\section{Population recovery: PVA-based evidence for habitat and spawner limitation}

We used our spatially explicit PVA model for shortnose sturgeon to evaluate extinction thresholds. Two thresholds of interest are minimum viable population size (MVP) and minimum habitat amount required to persist. To estimate MVP, we simulated the Ogeechee River population with a range of initial population sizes. An operational definition for MVP using this approach is the initial size for which at least $95 \%$ of replicate populations persist. We note that this operational definition does not, strictly speaking, identify a threshold as larger initial populations take longer to reach extinction even if the same outcome will eventually be reached. This is discussed by Jager et al. (2010) in a regional assessment of MVP thresholds for white sturgeon in the Pacific Northwest.

In simulations of the Ogeechee River, persistence over time periods of hundreds of years were not possible, but our results clearly show that this population would not be predicted to persist over such periods. Preliminary investigation of meta-population dynamics with immigration from the larger, nearby Altamaha River population suggests that the Ogeechee River population acts as a sink that is supported by its neighbors. For the short 20-year time horizon that we simulated, the MVP threshold was high if no 
additional sources of mortality (e.g., due to poor habitat) were simulated. However, with these factors the likelihood of persistence was fairly low (between 25 and 200 initial individuals) and we found that persistence did not continue to improve for large initial populations. This suggests that the MVP is low (a small number of successfully reproducing females can sustain the population) and that densitydependence, as represented in the model, is important.

The habitat requirement for shortnose sturgeon spawning populations was previously suggested to be 200 $\mathrm{km}$, based on a comparison of rivers lacking shortnose sturgeon with those supporting sizable populations (Kynard 1997). This distance is roughly the distance to the fall line, a geologic feature separating the Coastal Plain and Piedmont ecoregions, represents a natural barrier for fishes and marks a distinct break in the upstream distribution of many aquatic species in the Coastal Plain. We were therefore interested in further investigating the role of premature exposure to salinity by simulated spawning to a location in the river beyond $125 \mathrm{~km}$ (the distance investigated in our experiments). This required artificially extending physical habitat (data describing width, depth) beyond the $83 \mathrm{~km}$ that were characterized in the field (the Canoochee River enters at river km 53). However, preliminary simulations in which we artificially extended the river and upstream location of spawning did not continue to show a benefit, a result that we have not had the opportunity to investigate further. Now that we have a list of six likely locations for spawning, these PVA results could be made more realistic for the Ogeechee River population.

\section{Summer water quality limits PVA-simulated population recovery}

Nutrient pollution is an important cause of impairment (37\% of US river miles) and organic enrichment leading to low dissolved oxygen (24\% of US river miles) (USEPA 1994; Richter et al 1997). In blackwater rivers of the southeastern US, dissolved oxygen is below levels favorable for biota during a significant portion of the summer.

In this study, we evaluated the effects of summer habitat on shortnose sturgeon in the Ogeechee River using both field monitoring of water quality and population modeling. Our water quality monitoring in the Canoochee and Ogeechee Rivers shed light on the occurrence and frequency of hypoxic conditions in the lower river. Nearly $40 \%$ of biweekly DO measurements measured during the months from June to September were below $4 \mathrm{mg} \mathrm{L}^{-1}$. We also documented exports of organic $\mathrm{C}$ and $\mathrm{N}$ from Fort Stewart. These ultimately influence dissolved oxygen levels in estuaries downstream.

Researchers are starting to recognize the important role played by organic forms of $\mathrm{N}$ and $\mathrm{C}$ in blackwater stream metabolism (Kaushal and Lewis 2005). Algal growth and subsequent decomposition plays a smaller role in oxygen depletion than direct consumption of organic carbon by heterotrophic bacteria (Mallin and others 2004). Typical of blackwater systems (Meyer 1990), organic forms dominated both nitrogen and carbon in headwater streams on Fort Stewart. Concentrations of organic carbon were high and predominantly dissolved, with a high DOC:ON ratio. Our models for both OC and ON suggested a dilution effect following rainfall.

Based on our simulations, we believe that summer habitat, combined with small river size and the presence of rice canals may be limiting the shortnose sturgeon population in the Ogeechee River and causing it to act as a demographic sink. One interesting result of our simulations was the trade-off observed between mortality of juveniles that encountered elevated salinities prematurely in downstream areas and upstream starvation for juveniles that remained further upstream. This suggests a habitat squeeze for juveniles in smaller coastal rivers with limited access to spawning habitat farther upstream. The location of spawning habitat has not been confirmed in the Ogeechee River despite efforts to track 18 adults ( 3 females and 15 males) during one year (Peterson and Farrae 2011). However, juveniles have occasionally been sampled (Fleming et al. 2003).

\section{Coarse substrate required for spawning is rare}

Siltation is considered the single, greatest threat to aquatic life, affecting $45 \%$ of river miles in the east US (USEPA 1994, Richter and others 1997). Spawning habitat and substrate are considered to be important 
causes of declines for many sturgeon populations, and this factor was highlighted by the shortnose sturgeon recovery plan.

Our research addressed this question as follows. First, we learned during our workshop that tributaries of the Canoochee River on Fort Stewart is not considered important habitat for spawning adult shortnose sturgeon. Two remaining directions for research were 1) to understand sedimentation as an issue for other aquatic biota on Fort Stewart, and 2) to understand the potential for sedimentation in the Ogeechee River mainstem. We used a watershed study to address the on-base impacts of training on sediment concentrations in headwaters on Fort Stewart. We used side-scan sonar to evaluate sediment in the Ogeechee River. Each of these is summarized below.

Watershed study.-Concentrations of TSS measured in headwater streams draining Fort Stewart were variable and higher during event samples, with a mean value of $52.9 \mathrm{mg} \mathrm{L}^{-1}$ (range 7 to $941 \mathrm{mg} \mathrm{L}^{-1}$ ). Concentrations were particularly high after tropical storm Faye in August, 2008. TSS concentrations exceeding $80 \mathrm{mg} \mathrm{L}^{-1}$ have been associated with significant declines in macro-invertebrate density (Bilotta and others 2008). However, the biological significance of these levels likely depends on the frequency and duration of sediment loadings (Bilotta and Brazier 2008), and not just concentrations. Although 16\% of our event samples exceeded this limit, our non-event samples did not.

Our watershed study on Fort Stewart sought to examine the influences of military training activities. We found a positive association between TSS and tank training and a weaker positive association with roads and bare ground (Jager et al. 2011). Roads and barren areas used for training were found to be associated with elevated TSS in two studies on Fort Benning (Maloney and others 2005a, b; Houser and others 2006), but a negative response in a third (Bhat 2006). Military training in headwater watersheds at Fort Benning was also linked with high silt levels and reduced abundances of less-tolerant benthic invertebrates (Quist and others 2003, Maloney and Feminella 2006).

In our Canoochee River sampling, we detected elevated levels of TSS in headwater streams during one event that might be a concern for aquatic biota that inhabit headwater streams on Fort Stewart, and TSS levels were higher in those watersheds affected by tank training. TSS was also high downstream in the Canoochee samples below a large denuded training area on Fort Stewart.

Creating buffers of riparian vegetation surrounding water has been recommended before and is highlighted in environmental manuals produced by Fort Stewart (DEIS 2010) and other installations. Our ability to detect training effects on TSS suggests that either the policies have not yet been fully implemented or they are not having their intended effect. Future studies that combine our survey-based approach with more-intensive monitoring of the timing and intensity of training are needed to better understand the mechanisms for these empirical relationships involving military training. This would be the next step toward developing practical recommendations.

Side-scan sonar study.-Our side-scan sonar study suggests that suitable locations for spawning are rare. These results suggest that an absence of suitable spawning, incubation, and rearing substrate may be one factor limiting the Ogeechee population. In addition, it is likely that juvenile movement downstream into higher salinity habitat is hastened by the lack of interstitial habitat. The timing of the survey, which happened concurrently with our PVA modeling, did not allow us to represent specific spawning locations. Integrating these spawning locations into the PVA model is a next step in evaluating this population.

\section{Simulated mercury concentrations are below EPA's threshold}

We developed a model of mercury uptake for a shortnose sturgeon female and compared predicted $\mathrm{MeHg}$ concentrations based on measured prey concentrations with those measured. Both our modeling results and measurements suggest that levels are somewhat elevated, but they did not exceed the EPA threshold. We therefore rank mercury below three other potential threats preventing recovery of the Ogeechee population. However, we caution that levels in other species (largemouth bass) above the $1.0 \mathrm{mg} / \mathrm{kg}$ threshold have been caught in the Canoochee River on Fort Stewart. 


\section{Harvest mortality limits PVA-simulated population recovery}

Our PVA simulations compared population dynamics with and without by-catch. Our results suggest that by-catch could be a problem if mortality of captured sturgeon is similar to that published by Mark Connor in the Savannah River and if net avoidance is not significantly higher than what we assumed. We therefore conclude that this factor is not one that should be neglected.

\section{Implications for future research}

Our results suggest that future research to improve management for this species in southeastern rivers should focus on understanding the apparent sensitivity of shortnose sturgeon to availability of upstream river habitat for spawning and rearing of early lifestages. Our PVA modeling suggested to us a general theory for understanding coastal rivers and the anadromous populations that they support as a habitat "squeeze" for juveniles between density-dependent factors upstream and high salinities downstream. The length of suitable river habitat decreases seasonally as water temperatures rise. One can envision suitable river habitat as a series of accordions, shrinking and expanding seasonally. Locating refuge during periods of poor water quality in summer remains an important direction of research. We envision river habitat as being effectively "shortened" by man-made influences, including man-made canals and climate changes that result in sea-level rise. We, therefore, recommend research to understand future climate change effects and the potential for closing rice canals as an adaptive measure.

In southern populations, metapopulation connectivity between adjacent rivers is restricted temporally to winter (low temperatures) when salinity tolerance is higher. Coastal corridors connecting riverine populations are, therefore, potentially important during this time. PVA analysis is needed to evaluate alternative management options for improving habitat conditions in the lower river(s) and to test the generality of the theory proposed by this study for metapopulation support among sturgeon populations in rivers of different lengths. This effort would be best carried out in collaboration with field telemetry of individuals tagged in the three rivers, Altamaha, Ogeechee, and Savannah, which is needed to quantify straying rates and understand the age, gender, and circumstances of those migrating between rivers.

Sediment.-Our research highlighted the rarity of suitable coarse substrate for spawning for both Atlantic and shortnose sturgeon (Hook 2011). Higher-resolution surveys conducted at a slower speed might identify other locations. Although some hard-bottom areas may have been missed, the extremely low gradient and wide floodplain limits occasions for riverbed scouring (Hook 2011). Field work using egg mats and larval sampling is needed to confirm that shortnose sturgeon spawning occurs at these sites. In addition, we are interested in whether a general longitudinal pattern of increased incidence of cobble/gravel substrates farther upstream would be found, justifying the long spawning migration to distances closer to fall line. The next step in a PVA analysis should incorporate the locations found here into the PVA model to conduct a more realistic assessment of premature juvenile exposure to high salinities.

Water quality.-One goal of our study was to evaluate the role of Fort Stewart and military activities. We developed relationships that could now be useful for managing the robust redhorse (Moxostoma robustum) and other TES aquatic species found in smaller rivers and streams on Fort Stewart. In addition, our water quality monitoring demonstrated that Fort Stewart can potentially influence poor summer water quality in the larger Ogeechee River. To identify the impact of Fort Stewart, moreintensive monitoring of nutrient fluxes and organic carbon is needed to track development of adverse conditions in the estuary and coastal river. This would necessitate installation of flow gages or frequent monitoring of our staff gages, which would allow estimation of loadings from measured concentrations.

Harvest.-Our PVA results highlighted by-catch as one of three important factors reducing population persistence. However, the ability of sturgeon to avoid nets has not been assessed, nor has the sensitivity of our results to assumptions about avoidance. Field studies can be designed to estimate avoidance. The next step in this research is to obtain permission to use shad nets to catch tagged adult sturgeon during 
upstream migration. If the number of tagged adults in spawning conditions is combined with tracking sturgeon that escape the nets, a statistical estimate of net avoidance can be developed. Meanwhile, sensitivity analysis can be used to evaluate PVA results to assumed avoidance.

Atlantic sturgeon.-Although our project focused on the shortnose sturgeon, some of our findings and modeling results also apply to the Atlantic sturgeon, species that is also present in this river system.

Farrae et al. (2009) estimated the abundance of age 1 Atlantic sturgeon in the Ogeechee River to be 450 in 2007, and numerous other researchers have captured age 1 Atlantic sturgeon in the system. Listing of Atlantic sturgeon under the Endangered Species Act is imminent. The individual-based modeling approach used in our PVA lends itself to understanding potential competitive interactions between two such species. 


\section{LITERATURE CITED}

Alam, SK, Brim, MS, Carmody, GA and Parauka, FM (2000) Concentrations of Heavy and Trace Metals in the Muscle and Blood of Juvenile Gulf Sturgeon (Acipenser oxyrinchus desotoi) from the Suwannee River, Florida. J. Envir. Sci. Health. Part.A. 35:645-660.

Alber M, Sheldon JE (1999) Use of a date-specific method to examine variability in the flushing times of Georgia estuaries. Estuarine Coast and Shelf Science 49:469-482.

Anderson DR (2008) Model Based Inference in the Life Sciences: A Primer on Evidence. Springer Science $184 \mathrm{p}$.

Ator SW, Olsen AR, Pitchford AM, Denver, JM (2003) Application of a multi-purpose unequalprobability stream survey in the Mid-Atlantic Coastal Plain. Journal of the American Water Resources Association 39:873-886

Badiani A, Anfossi A, Fiorentini L, Gatta PP, Manfredini M, Nanni N, Stipi S, Tolomelli B. 1996. Nutritional composition of cultured sturgeon (Acipenser spp.). Journal of food composition and analysis 9:171-190.

Bain MB, Haley N, Peterson DL, Arend KK, Mills KE, Sullivan PJ (2007) Recovery of a US Endangered Fish. PLoS ONE 2(1): e168. doi:10.1371/journal.pone.0000168

Beamis FWH, Jebbink JA, Rossiter A, Noakes DLG. (1996). Growth strategy of juvenile lake sturgeon (Acipenser fulvescens) in a northern river. Canadian Journal of Fisheries and Aquatic Sciences 53(3): 481-489.

Bevelhimer MS, Jager HI (submitted) A bioenergetic model for shortnose sturgeon. Environmental Biology of Fishes.

Bevelhimer, MS (2002) A bioenergetics model for white sturgeon Acipenser transmontanus: assessing differences in growth and reproduction among Snake River reaches. Journal of Applied Ichthyology 18:550-556.

Bilotta GS, Brazier RE, Haygarth PM, Macleod CJA, Butler R, Granger S, Krueger T, Freer J, Quinton JN (2008) Rethinking the contribution of drained and undrained grasslands to sediment-related water quality problems. Journal of Environmental Quality 37:906-914

Bonzongo JJ, Lyons WB (2004) Impact of land use and physiochemical settings on aqueous methylmercury levels in the Mobile-Alabama River system. Ambio 33:328 - 333.

Buhler DR, Claeys RR, Shanks WE (1973) Mercury in Aquatic Species from the Pacific Northwest. in Mercury in the Western Environment, Continuing Education Publications, Corvallis, OR. p. 5975. USPHS (ES 00210).

Burnham KP, Anderson DR (2002) Model selection and multimodel inference: a practical informationtheoretic approach. 2nd Edition. Springer-Verlag, New York, USA. 488 pp.

Collins MR, Rogers SG, Smith TIJ, Moser ML (2000a) Primary factors affecting sturgeon populations in the southeastern United States: Fishing mortality and degradation of essential habitats. pp. 917928.

Collins MR, Post WC, and Rust, DC (2000b) Distribution of shortnose sturgeon in the Lower Savannah River. Final report to the Georgia Ports Authority. 
Collins MR, Post WC, and Rust, DC, Smith TJ (2002) Habitat use and movements of juvenile shortnose sturgeon in the Savannah River, Georgia South Carolina. Transactions of the American Fisheries Society 131, 975-979.

DEIS (Draft Environmental Impact Statement) (2010) Chapter 3, The DEIS for Training Range and Garrison Support Facilities Construction and Operation at Fort Stewart, Georgia. March, 2010.

DeVries, RJ (2006) Population dynamics, movements, and spawning habitat of the shortnose sturgeon, Acipenser brevirostrum, in the Altamaha River System, Georgia. M.S. Thesis, University of Georgia, Athens, Georgia.

Farrae DJ (2010) Habitat use and movements of shortnose sturgeon in the Ogeechee River, Georgia. MS thesis. University of Georgia at Athens.

Farrae DJ, Peterson DL (2010) Population dynamics and essential habitats of shortnose sturgeon in the Ogeechee River, Georgia. Final project report to the National Marine Fisheries Service. 114 pp

Fleming JE, Bryce TD, Kirk JP (2003) Age, growth, and status of shortnose sturgeon in the Lower Ogeechee River, Georgia. Proceedings of the Annual Conference Southeast Association of Fish and Wildlife Agencies 57: 80-91.

Fox, D. Hightower and J. E. Parauka, F. M., 2000: Gulf sturgeon spawning migration and habitat in the Choctawhatchee River system, Alabama-Florida. Transactions of the American Fisheries Society. 129: 811-826.

Gassman PW, Reyes MR, Green CH, Arnold JG (2007) The soil and water assessment tool: Historical development, applications, and future research directions. Transactions of the American Society of Agricultural and Biological Engineering (ASABE) 50:1211-1250

Gessner, J, Wirth M, Kirschbaum F, Patriche N (2002) Processing techniques for caviar and their effects on product composition. International Review of Hydrobiology 87(5-6):645-650.

Homer CCH, Yang L, Wylie B, Coan M (2004) Development of a 2001 National Landcover Database for the United States. Photogrammetric Engineering and Remote Sensing 70: 829-840

Hook JD (2011) Sturgeon habitat quantified by side-scan sonar imagery. Masters Thesis. University of Georgia, Athens. Advisors: Nathan P. Nibbelink and Douglas L. Peterson.

Houser JN, Mulholland PJ and Maloney KO (2006) Upland disturbance affects headwater stream nutrients and suspended sediments during baseflow and stormflow. Journal of Environmental Quality 35:352-365

Hughes WB, Abrahamsen TA, Maluk TL, Reuber EJ, Wilhelm LJ (2000) Water Quality in the Santee River Basin and Coastal Drainages, North and South Carolina, 1995-98: U.S. Geological Survey Circular 1206, 32 p., on-line at http://pubs.water.usgs.gov/circ1206/.

Jager HI, Bevelhimer, MS, King, R, and Smith, K (2011) Landscape influences on headwater streams on Fort Stewart, Georgia, USA. Environmental Management 4: 1227-1239

Jager HI, Lepla, KB, Van Winkle, W. James, BW, McAdam, SO (2010). The elusive minimum viable population size for white sturgeon. Transactions of the American Fisheries Society 139: 15511565

Kaushal SS, Lewis WM, Jr (2005) Fate and transport of organic nitrogen in minimally disturbed montane streams of Colorado, USA. Biogeochemistry 74:303-321

Kynard B (1997) Life history, latitudinal patterns, and status of the shortnose sturgeon, Acipenser brevirostrum. Environmental Biology of Fishes 48:319-334. 
Lachat, Inc. (1994) Ammonium in brackish or seawater -- QuickChem Method 31-107-06-1-A. Lachat Instruments, 6645 West Mill Road, Milwaukee, WI 53218.

Lachat, Inc. (1998) Phosphate in brackish or seawater -- QuickChem Method 31-115-01-3-A. Lachat Instruments, 6645 West Mill Road, Milwaukee, WI 53218.

Lachat, Inc. (1999) Nitrate and/or nitrite in brackish or seawater -- QuickChem Method 31-107-04-1-A. Lachat Instruments, 6645 West Mill Road, Milwaukee, WI 53218.

LaHaye M, Branchaud A, Gendron M, Verdon R, Fortin R (1992) Reproduction, early life history, and characteristics of the spawning grounds of the lake sturgeon (Acipenser fulvescens) in Des Prairies and L_Assomption rivers, near Montreal, Quebec. Can. J. Zool. 70, 1681-1689.

Latif MA, Bodaly RA, Johnston TA, Fudge RJP (2001) Effects of environmental and maternally derived methylmercury on the embryonic and larval stages of walleye (Stizostedion vitreum) Environmental Pollution, Volume 111, Issue 1, January 2001, Pages 139-148

Leaner JJ,Mason RP (2002) Factors controlling the bioavailability of ingested methylmercury to channel catfish and Atlantic sturgeon. Environ, Sci. Technol. 36:5124-5129.

MacDonald DD, Ikonomou MG, Rantalaine A-L, Rogers IH, Sutherland D, Van Oostdam J (1997) Environmental Toxicology and Chemistry 16:479-490.

Mallin MA, McIver MR, Ensign SH, Cahoon LB (2004) Photosynthetic and heterotrophic impacts of nutrient loading to blackwater streams. Ecological Applications 14:823-838

Maloney KO, Feminella JW (2006) Evaluation of single- and multi-metric benthic macroinvertebrate indicators of catchment disturbance over time at the Fort Benning Military Installation, Georgia, USA. Ecological Indicators 6:469-484

Meyer JL (1990) A blackwater perspective on riverine ecosystems. BioScience 40:643-651

Morel FMM, Krapiel AML, and Amyot M (1998) The chemical cycle and bioaccumulation of mercury, Annual Review of Ecology and Systematics 29:543-566.

Mulholland, P. J., J. N. Houser, and K. O. Maloney (2005) Stream diurnal dissolved oxygen profiles as indicators of in-stream metabolism and disturbance effects: Fort Benning as a case study. 14 Ecological Indicators 5:243-252.

Niklitschek EJ and Secor DH (2009) Dissolved oxygen, temperature and salinity effects on the ecophysiology and survival of juvenile Atlantic sturgeon in estuarine waters: I. Laboratory results. Journal of Experimental Marine Biology and Ecology 381: S150-S160.

NMFS (National Marine Fisheries Service) (1998) Final Recovery Plan for the Shortnose Sturgeon Acipenser brevirostrum. U.S. Department of Commerce, National Oceanic and Atmospheric Administration, National Marine Fisheries Service, 113 pp.

Paller MH, Bowers, JA Littrell JW, Guanlao AV (2004) Influences on mercury bioaccumulation factors for the Savannah River. Archives of Environmental Contamination and Toxicology. 46:236-243.

Perrin CJ, Rempel LL, Rosenau ML (2003) White sturgeon spawning habitat in an unregulated river: Fraser River, Canada. Transactions of the American Fisheries Society 132: 154-165.

Peterson DL, Farrae DJ (2011) Population dynamics and essential habitats of shortnose sturgeon in the Ogeechee River, Georgia. Transactions of the American Fisheries Society 140(6): 1540-1546.

Pinheiro JC, Bates DM (2000) Mixed-effects Models in S and S-Plus. Springer-Verlag LLC, New York

Pringle CM, Freeman MC, Freeman BJ (2000) Regional effects of hydrologic alterations on riverine macrobiota in the new World: Tropical-temperate comparisons. BioScience 50:807-823 
Quist MC, Fay PA, Guy CS, Knapp AK, Rubenstein BN (2003) Military training effects on terrestrial and aquatic communities on a grassland military installation. Ecological Applications 13:432-442

Richter BD, Braun DP, Mendelson MA, Master LL (1997) Threats to imperiled freshwater fauna. Conservation Biology 11(5):1081-1093

Rogers GS and W Weber (1994) Occurrence of shortnose sturgeon (Acipenser brevirostrum) in the Ogeechee-Canoochee river system, Georgia, during the summer of 1993. Final report to the Nature Conservancy of Georgia for the U.S. Army, Fort Stewart, Georgia.

Secor DH, Niklitschek EJ (2001) Hypoxia and Sturgeons. Report to the Chesapeake Bay Program Dissolved Oxygen Criterion Team. Technical Report Series No. TS-314-01-CBL.

Sheldon JE, Alber M (2005) Comparing transport times through salinity zones in the Ogeechee and Altamaha River estuaries using Squeezebox. In: KJ Hatcher (Editor), Georgia Water Resources Conference, The University of Georgia, Athens, GA, p. 4.

Smith, TIJ, McCord, JW, Collins, MR and Post, WC (2002) Occurrence of stocked shortnose sturgeon Acipenser brevirostrum in non-target rivers. Journal of Applied Ichthyology, 18:470-474.

Trudel M, Rasmussen, JB (2001) Predicting mercury concentration in fish using mass balance models. Ecological Applications 11:517-529.

Trudel M, Rasmussen JB (2006) Bioenergetics and mercury dynamics in fish: a modeling perspective. Canadian Journal of Fisheries and Aquatic Sciences 63:1890-1902.

USEPA (United States Environmental Protection Agency) (1994) The quality of our Nation's water: 1992. EPA 841-S-94-002. EPA Office of Water, Washington, DC

USEPA (United States Environmental Protection Agency) (2000) Ambient water quality criteria recommendations: Rivers and streams in nutrient ecoregion XII. EPA-822-B-00-021

USEPA (United States Environmental Protection Agency) (2004) Total Maximum Daily Load for Total Mercury in Fish Tissue in the Canoochee River. August, 2004.

USEPA (United States Environmental Protection Agency) (2005) Total Maximum Daily Load Evaluation for Twenty-three Stream Segments in the Ogeechee River Basin for Dissolved Oxygen. January, 2005. EPA 841-S-94-002. EPA Office of Water, Washington, DC

Webb, MAH, Feist GW, Fitzpatrick MS, Foster EP, Schreck CB, Plumlee M, Wong C, Gundersen DT (2006) Mercury concentrations in gonad, liver, and muscle of white sturgeon Acipenser transmontanus in the lower Columbia River. Archives of Environmental Contamination and Toxicology 50(3): 443-451.

Weiner, JG, Spry, DJ (1996) Toxicological significance of mercury in freshwater fish. pp. 297 -339 in Environmental Contaminants in Wildlife: Interpreting Tissue Concentrations, WN Beyer, GH Heinz, and AW Redmon-Norwood, eds. Special Publication of the Society of Environmental Toxicology and Chemistry, Lewis Publishers, Boca Raton, Florida, USA.

Zuur AF, Leno EN, Walker N, Saveliev AA, Smith GM (2009) Mixed Effects Models and Extensions in Ecology with R. Springer-Verlag LLC, New York 
APPENDIX A.

LIST OF SCIENTIFIC PUBLICATIONS 


\section{Presentations}

- Farrae, DJ and DL Peterson. 2008. Shortnose sturgeon in the Ogeechee River. Presentation to the 2008 Annual meeting of the American Fisheries Society in Ottawa, Canada. Symposium on Sustainable Sturgeon.

- Jager, HI, MS Bevelhimer, DL Peterson and DJ Farrae. 2009. PVA modeling to evaluate factors limiting shortnose sturgeon (Acipenser brevirostrum) in the Ogeechee River. 2009 Annual meeting of the American Fisheries Society, Nashville, TN

- Farrae, DJ and DL Peterson. 2009. Evidence of a source-sink population of shortnose sturgeon in the Ogeechee and Altamaha Rivers, GA. 2009 Annual meeting of the American Fisheries Society, Nashville, TN

- Jager, HI, MS Bevelhimer, DL Peterson and DJ Farrae. 2010. Habitat influences on shortnose sturgeon in the Ogeechee River. Presentation to NOAA Fisheries, Cedar Key, FL.

- Jager, HI participated on Review Panel for modeling efforts to determine trends in Gulf sturgeon, as described in "Status of Gulf Sturgeon Acipenser oxyrinchus desotoi in the Gulf of Mexico" by B. Pine and S. Martell, at the invitation of NOAA-Fisheries.

- Jager, HI and JJ Cech. 2011. Biological factors related to sturgeon passage: Theory and practice. Presentation at a Lake Sturgeon Passage Workshop held by the Great Lakes Fisheries Trust, February 1-2, 2011 Detroit, MI.

- Jager, HI, MS Bevelhimer, DL Peterson and DJ Farrae. 2011. Modeling Ogeechee River shortnose sturgeon. Sturgeon Workshop focused on recovery plans for shortnose sturgeon and the upcoming decision to list Atlantic sturgeon, February 8-10, 2011 in Alexandria, VA. http://www.nero.noaa.gov/prot_res/atlsturgeon/sws2.html

- Peterson, DL. 2011. New population information for sturgeon in the Altamaha River. Sturgeon Workshop, February 8-10, 2011 in Alexandria, VA.

\section{Awards}

- Dr. Douglas Peterson was awarded the 2010 Creative Research award by the Univ. of Georgia Research Foundation: http://creativeresearch.uga.edu/index.php/recipients/detail/peterson-doug/

\section{Publications}

- Science Daily article, August 7, 2007. "Can shortnose sturgeon fish survive?" www.sciencedaily.com/releases/2007/08/070806120615.htm

- Jager, HI, MS Bevelhimer, RL King, and KA Smith. 2011. Landscape influences on headwater streams on Fort Stewart, Georgia, USA. Environmental Management 4: 1227-1239 http://www.springerlink.com/openurl.asp?genre=article\&id=doi:10.1007/s00267-011-9722-4

- Peterson DL and DJ Farrae. In press. Population dynamics and essential habitats of shortnose sturgeon in the Ogeechee River, Georgia. Transactions of the American Fisheries Society.

- Bevelhimer MS and HI Jager. Submitted for publication. A Bioenergetics Model of Growth and Reproduction for Shortnose Sturgeon in the Southern US. Ecological Modelling

\section{Theses and Dissertations}

- Hook, John David. 2011. Sturgeon habitat quantified by side-scan sonar imagery. Masters Thesis, University of Georgia, Athens. Under the direction of Nathan P. Nibbelink and Douglas L. Peterson. 
- Farrae, Daniel. 2011. Population dynamics and movements of shortnose sturgeon in the Ogeechee River, Georgia. Masters Thesis, University of Georgia, Athens. Under the direction of Douglas L. Peterson. 